\title{
Onorden
}

\section{The coexistence of two Ecolabels}

- The Nordic Ecolabel and the EU Ecolabel in the Nordic Countries

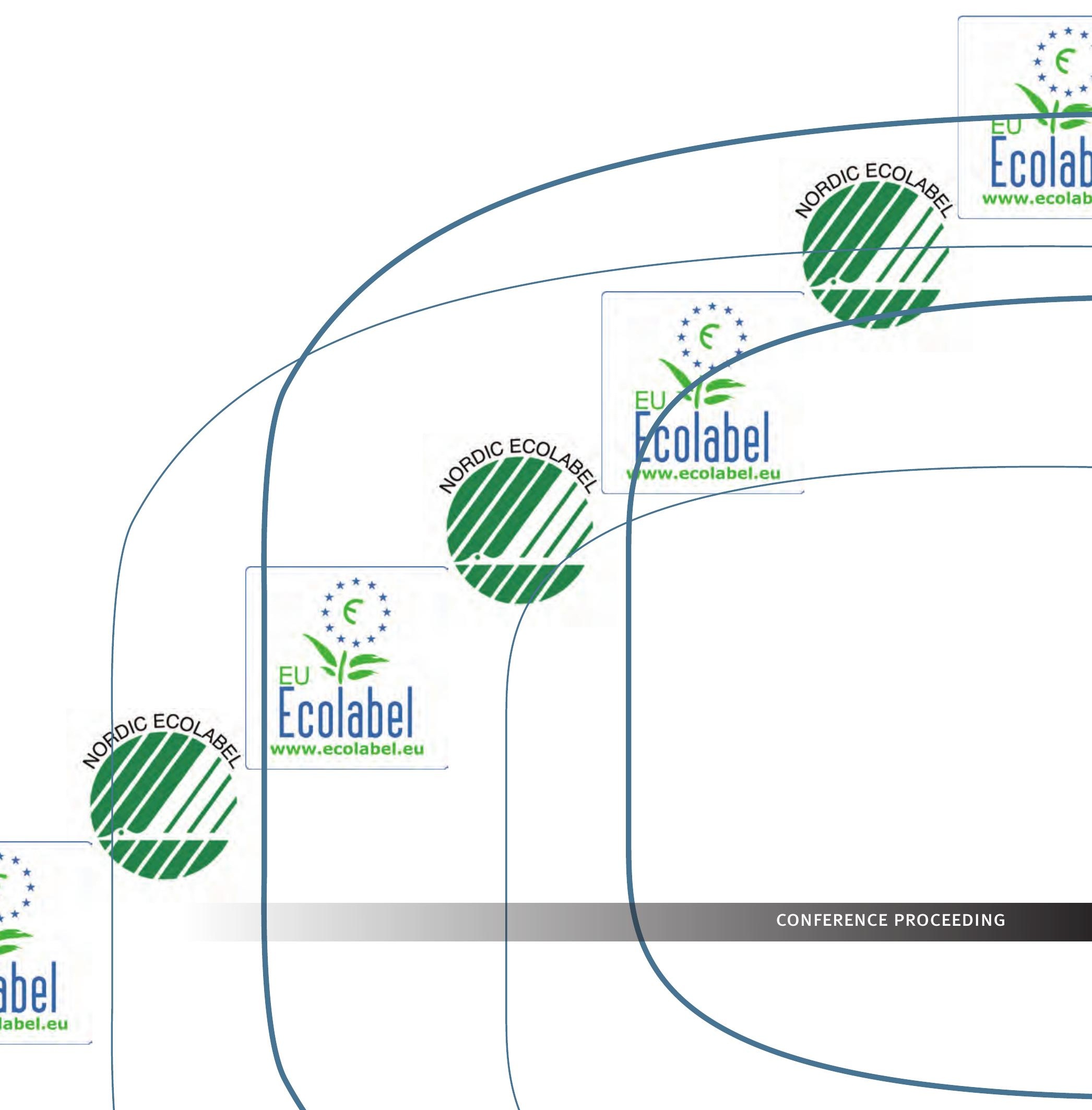



4 norden 



\section{The coexistence of two Ecolabels \\ - The Nordic Ecolabel and the EU Ecolabel in the Nordic Countries}

Peter Lange, Ulrik Boe Kjeldsen, Maja Tofteng, Anja Krag and Kasper Lindgaard

TemaNord 2014:525 
The coexistence of two Ecolabels

- The Nordic Ecolabel and the EU Ecolabel in the Nordic Countries

Peter Lange, Ulrik Boe Kjeldsen, Maja Tofteng, Anja Krag and Kasper Lindgaard

ISBN 978-92-893-2765-7

ISBN 978-92-893-2766-4 (EPUB)

http://dx.doi.org/10.6027/TN2014-525

TemaNord 2014:525

ISSN 0908-6692

(c) Nordic Council of Ministers 2014

Layout: Hanne Lebech

This publication has been published with financial support by the Nordic Council of Ministers. However, the contents of this publication do not necessarily reflect the views, policies or recommendations of the Nordic Council of Ministers.

www.norden.org/en/publications

\section{Nordic co-operation}

Nordic co-operation is one of the world's most extensive forms of regional collaboration, involving Denmark, Finland, Iceland, Norway, Sweden, and the Faroe Islands, Greenland, and Åland.

Nordic co-operation has firm traditions in politics, the economy, and culture. It plays an important role in European and international collaboration, and aims at creating a strong Nordic community in a strong Europe.

Nordic co-operation seeks to safeguard Nordic and regional interests and principles in the global community. Common Nordic values help the region solidify its position as one of the world's most innovative and competitive.

\section{Nordic Council of Ministers}

Ved Stranden 18

DK-1061 Copenhagen K

Phone $(+45) 33960200$

\section{www.norden.org}




\section{Content}

Preface.

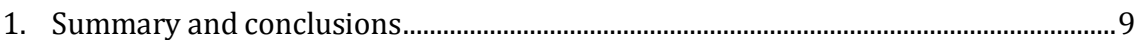

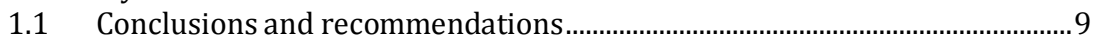

2. About the ecolabels.................................................................................................... 15

2.1 About the Swan Label ........................................................................................ 15

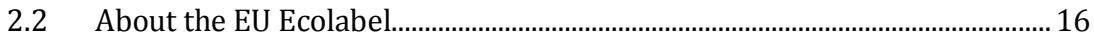

3. Methodology ........................................................................................................ 19

3.1 Methodology for the chapter on positioning and success ............................. 22

4. Positioning and success......................................................................................... 25

4.1 Participation of companies across product groups and countries ............... 25

4.2 The prevalence of the Swan Label.................................................................... 26

4.3 The prevalence of the EU Ecolabel................................................................... 30

4.4 Strengths of the Swan Label and the EU Ecolabel............................................. 32

4.5 The reasons for acquiring an ecolabel .............................................................. 34

4.6 The Swan Label is well-known among consumers.......................................... 37

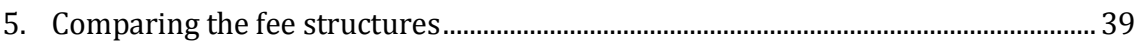

5.1 Differences in the application, renewal and extension fees...........................39

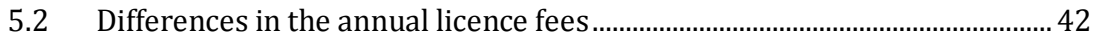

5.3 Administrating the ecolabels and prioritisation ............................................. 46

5.4 The direct costs of the ecolabels are important for some companies

- less so for others

5.5 Possibilites to lower the fees and administrative burdens when applying for both ecolabels.............................................................................. 49

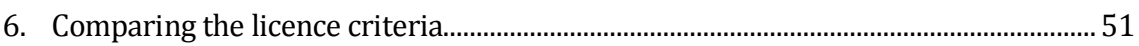

6.1 Heat pumps - differences within the width of the criteria............................. 51

6.2 Laundry detergents and stain removers - differences within the criteria mode and content .................................................................................... 52

6.3 Floor coverings - differences within the width of the criteria........................53

6.4 Tissue paper - noteworthy differences in content....................................... 54

6.5 Cleaning products - differences in width and mode............................................ 54

6.6 Hand dishwashing detergents - noteworthy differences in content............55

6.7 Dishwasher detergents - differences on all dimensions................................ 56

6.8 Copy and printing/graphic paper - high level of similarity but slight differences in content .......................................................................... 57

6.9 Systematic differences across product types ................................................... 58

7. International experience on co-existence between ecolabels.....................................61 61

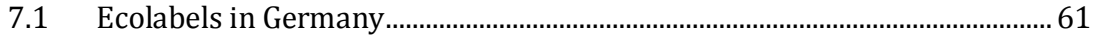

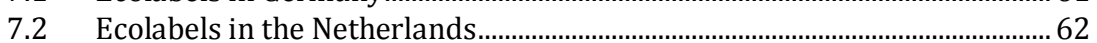

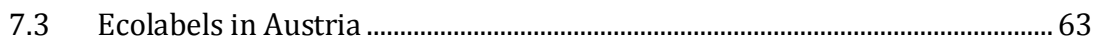

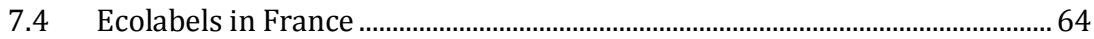




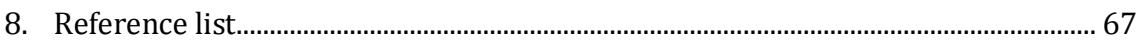

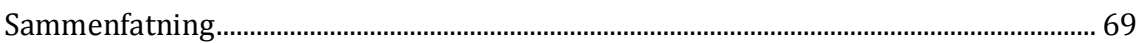

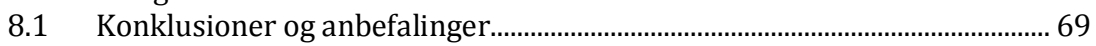

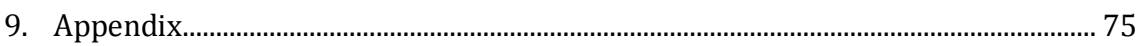

\section{List of figures and tables}

Figure 1: Similarities and differences between the Swan

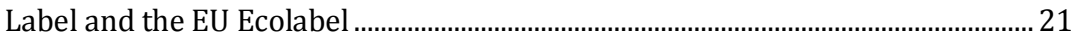

Figure 2: Reasons for choosing the Swan Label/the EU Ecolabel .................................. 35

Figure 3: Reasons for choosing the Swan Label over the EU Ecolabel .......................... 36

Figure 4: Companies comparing the fees of the two labels before

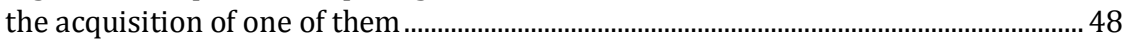

Figure 5: Companies view on having both ecolabels ....................................................... 49

Table 1: The sample space of interviews performed ..................................................... 20

Table 2: The number of answers given in the survey among companies..................... 20

Table 3: Swan Label certified product categories with most licence holders............. 26

Table 4: Swan Label certified product categories with most licence

holders, services not included .................................................................................. 27

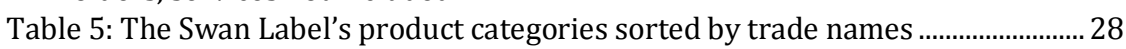

Table 6: Countries ranked by number of Swan Label licence

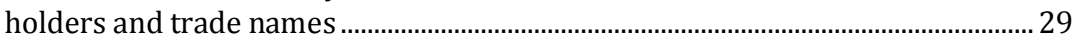

Table 7: EU Ecolabel product categories with most licence holders................................ 30

Table 8: EU Ecolabel product categories with most trade names.................................. 31

Table 9: Countries ranked by number of EU Ecolabel trade names and licence holders ............................................................................................. 32

Table 10: Comparative strengths of the Swan Label and EU Ecolabel across product catego-ries in the Nordic countries.................................................. 33

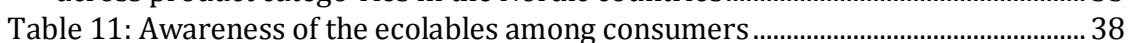

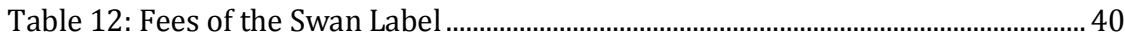

Table 13: Fees of the EU Ecolabel ...................................................................................... 41

Table 14: Examples of differences in the fees................................................................... 42

Table 15: Variation in EU Ecolabel annual fees.................................................................. 44

Table 16: Differences in annual fees between the EU Ecolabel and Swan Ecolabel for products and services........................................................ 45

Table 17: Examples of maximum fees for an ecolabelled cleaning product................ 46

Table 18: Criteria differences: Comparison of criteria across eight product categories ............................................................................................... 59

Table 19: Sources for chapter on licence holders and trade names .............................. 75

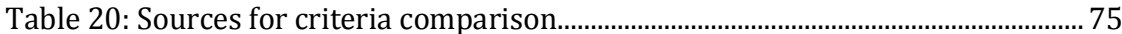

Box 1: Fees for the ecolabels......................................................................................... 41

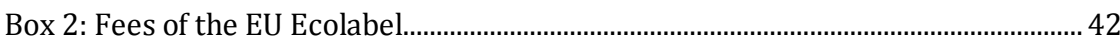

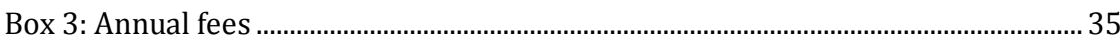




\section{Preface}

This analysis is the product of the project "Svanen-2015 - Utvärdering av förhållandet mellan Svanen \& EU Ecolabel." The project is commissioned by the Swan group under the working group for Sustainable Consumption and Production (HKP-gruppen) of the Nordic Council of Ministers.

The project's purpose is to provide new knowledge on how the Swan Label co-exists with the EU Ecolabel in the Nordic countries. This analysis looks closer at the synergies and positioning between the fee structures and criteria of the two ecolabels, the dissemination and success of the two labels within different product groups and the experience with co-existence between the EU Ecolabel and other national and regional ecolabels. The analysis does this by performing interviews with representatives from the five Nordic ecolabelling secretariats, interviews with representatives from ecolabelling secretariats from France, Germany, the Netherlands and Austria as well as through a desk research of available material.

The analysis is conducted by DAMVAD (see www.damvad.com) with expert assistance from Åke Thidell, Lund University.

The report is structured as follows:

In chapter 1, the conclusions of the analysis are given and recommendations for the further work with the Swan Label are outlined. Chapter 2 introduces the two ecolabels while Chapter 3 presents the methodology for the analysis and chapter 4 looks closer at the positioning and success of the two labels. Chapter 5 examines the fee structures of the two labels, while chapter 6 compares the licencing criteria of the Swan Label and the EU Ecolabel. Chapter 7 presents cases from four countries outside the Nordics having parallel ecolabelling systems. The appendix presents sources for the analysis. At the end, a summary in Danish is provided.

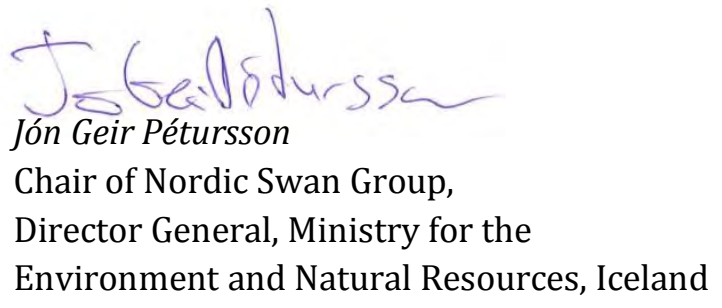





\section{Summary and conclusions}

The Nordic Council of Ministers has asked DAMVAD to perform an analysis of the relationship and co-existence between the Nordic Ecolabel the Swan Label - and the EU Ecolabel, in the Nordic countries. The purpose of the analysis is to look deeper into the synergies and differences between the two labels and the following three themes are investigated:

- The positioning and success of the Swan Label and the EU Ecolabel within different product categories.

- The synergy and positioning between the fee and criteria structures of the Swan Label and the EU Ecolabel.

- The experience with co-existence between the EU Ecolabel and other national and regional ecolabels.

To be able to perform the analysis a number of methodological steps and methods have been taken involving desk research, interviews and analysis of available data from the websites of the national ecolabelling secretariats of the Nordic countries. Finally, a survey has been conducted among the holders of the Swan Label, the EU Ecolabel or both, in the Nordic countries.

\subsection{Conclusions and recommendations}

\subsubsection{The Swan Label dominates within service industries}

The analysis has shown that the Swan Label has a dominant position in the Nordic countries and that it is used to a substantially higher degree among Nordic companies than the EU Ecolabel is. In addition, the two labels differ significantly in their position across industries. The analysis shows that the Swan Label is especially well positioned within services such as hotels, printing companies, etc. and within products such as household cleaning products, cosmetics, etc. The strong position in services is in part due to larger chains of stores having all of their stores Swan labelled. The EU Ecolabel has a strong position within campsite services and among products within categories such as tex- 
tiles, painting, paper products, etc. When comparing positions across countries, Sweden is a frontrunner for Swan labelled products and services followed by Denmark, Norway and Finland while for the EU Ecolabel Denmark is the frontrunner.

\subsubsection{The Swan Label is more expensive, but users are not generally price sensitive}

Furthermore, the analysis has shown that the fees for the Swan Label in general are higher than those of the EU Ecolabel. However, exceptions to this occur. The application fees are higher for the Swan Label, with the exception for large enterprises, where the fees will become similar if a new price structure for the EU Ecolabel is implemented in the Nordic countries. For renewal fees, the Swan Label is more expensive for micro enterprises but less exensive for large enterprises, under the new price structure for the EU Ecolabel. Regarding annual fees, the EU Ecolabel is less costly for the companies concerning products, regardless of whether the current or old fee system is applied. For services, the EU Ecolabel is less expensive under the current fee system and similar priced as the Swan Label under the new system. However, the EU Ecolabel will have a maximum fee under the new fee system, which, for products, is lower than the Swan Label maximum fee, but for services is higher than the maximum fee for the Swan Label.

Moreover, the fee structure of the EU Ecolabel is slightly simpler than that of the Swan Label. Calculated examples of the fees a company has to pay show large differences with the EU Ecolabel being the least costly. However, the analysis also shows that while some companies consider the direct costs of the label more than $50 \%$ of companies carrying either the Swan Label or the EU Ecolabel do not pay close attention to these costs, but are driven by consumer demand, the wish to obtain/sustain a green profile, etc. Also, in many cases the Swan Label has a strong brand and is well-known among consumers making it the obvious choice.

\subsubsection{Swan Label criteria emphasise detail and control visits}

Comparing the criteria of the two ecolabels is a complicated task. The criteria are not structured in the same manner and do not always cover the same proporties - even when categories are overlapping. However, there seems to be systematic differences across product categories when looking at the width (the broadness of what is covered by the criteria), the mode (how the criteria are applied, e.g. through point systems) and 
the content (what the criteria pay attention to, e.g. environmentalrequirements, packaging, etc.) of the criteria. Within the width of the criteria differences can be seen in how broad the ecolabels certify - in some instances the Swan Label is broader in coverage, in others it is the EU Ecolabel. Within mode, the Swan Label demands inspection visits, while this is voluntary under the EU Ecolabel, but often performed in the Nordic countries. Within content the ecolabels often adress the same themes but do so with varying strengths. The Swan Label's criteria, in most cases, seem more comprehensive and with a high level of detail.

\subsubsection{The international outlook: differentiation and assimilation}

Finally, the analysis looks at the strategies of other countries when having two ecolabels. The German situation is much similar to the Nordic with a very strong national ecolabel besides the EU Ecolabel. As such, Germany has chosen a differentiation strategy and to sustain a strong national label. In the Nertherlands, an assimilation strategy has been chosen: when criteria are developed within a product category covered by both the national label and the EU Ecolabel the national criteria are phased out and replaced by the EU Ecolabel criteria. In Austria a strategy of both assimilating and differentiating has been chosen. For some categories the EU Ecolabel criteria have been adopted as criteria for the national Ecolabel as well. For other product categories, however, it has been found that the EU Ecolabel criteria are not strong enough and stricter criteria for the national ecolabel have been developed. Finally, France has chosen a completely different strategy for their national ecolabel and only establishes criteria within categories not covered by the EU Ecolabel.

\section{Based on the analysis performed and the conclusions above the} following is recommended for the future work with the Swan Label

- Consolidate and build on the strong position in service industries A strong comparative position in service industries is a clear advantage and an axis of differentiation for the Swan Label. In addition, services are of growing importance to modern economies like the Nordics and it is often shown how services constitute up 
$70-80 \%$ of a country's GDP and continue to grow. ${ }^{1}$ The comparative position of the Swan Label within services such as hotels and printing facilities is, therefore, important and should be consolidated further.

Furthermore, another study on the Swan Label ${ }^{2}$ has shown that the impact on behaviour of the Swan Label is larger for service companies than it is for production companies. This impact is related to companies' costs but in particular to their environmental impact. This indicates "low-hanging fruits" to pick for both the service companies and the future of the Swan Label.

This strong position within services seems to be most evident in Sweden and less so in the other countries. However, given the higher impacts for service companies and the success in Sweden - also bearing in mind the competition with other eoclabels - it should be considered to consolidate and build on the strong position in service industries across all the Nordic countries. However, it is noted that there is a significantly higher workload for the secretariats in licencing service companies compared to physical products.

- Prioritise expansion in high-growth industries specific to the Nordics Following this train of thought, focusing the development and uptake of the Swan label in other high growth areas specific to Nordic economies can be a fruitful venue for the Swan Label - both in terms of expanding the label and creating added value through differentiation from the EU Ecolabel.

- Become the "high-end" label in contested industries As described above, other countries having a national ecolabel and the EU Ecolabel have chosen various strategies for the co-existence of those labels. The countries with strong national ecolabels have chosen a differentiation strategy and seek to enforce the strong positions of the national ecolabels.

The Swan Label has a similar position in the Nordic countries and an enforcement of this position can be conducted in several ways:

- First of all and as partly mentioned above, one strategy can be to focus on industries and sectors of growth to be able to position the Swan Label among the strong industries and sectors of the future.

\footnotetext{
${ }^{1}$ See e.g. OECD databank website, http://stats.oecd.org/

2 "The Nordic Swan and companies - Is it worthwhile to acquire the Swan label?", DAMVAD 2013 for the Nordic Council of Ministers, forthcoming.
} 
- Another possibility is to choose the French strategy and more aggressively differentiate from the EU Ecolabel and focus on product categories in which the EU Ecolabel is not present.

- Third, the Swan Label can be differentiated from the EU Ecolabel by consistently setting the bar higher and creating stricter criteria. Among most of the companies surveyed and interviewed the Swan Label is already considered stricter than the EU Ecolabel and the comparison of criteria has shown that this is the case in many instances. Such a strategy would position the Swan Label as a "high-end" ecolabel chosen by companies willing to "go the extra mile." Naturally, this will have positive environmental impacts.

- Communicate the advantages of the Swan Label clearly Several interviewed and surveyed companies indicate a wish for the communication of the advantages of the Swan Label to be clearer. They want to be able to communicate to their costumers in a short, concrete and precise manner what the advantages of the Swan Label are.

Such a precise and concrete communication can be advantageous for the Swan Label itself, as it will strengthen the awareness and position of the Swan Label among the consumers and companies even further. One possibility is to incorporate such short and precise statements of the advantages of the label into the criteria documents, as a possibility for the companies to utilise.

- Sustain the Nordic profile

The Swan Label is a strong brand and well-known in all of the five Nordic countries. However, there are significant differences in the number of licence holders and trade names across the five countries. To sustain the Nordic profile of the Ecolabel, it is important that the Swan Label has high priority in all five countries and continues to be developed and marketed as the leading ecolabel in all of the Nordic countries. 



\section{About the ecolabels}

\subsection{About the Swan Label}

The Nordic Ecolabel (also known as and onwards mentioned as the Swan Label) is the official Ecolabel of the Nordic countries, i.e. Denmark, Finland, Iceland, Norway and Sweden. The Swan Label is an initiative by the Nordic Council of Ministers and was established in 1989. The purpose of the Swan Label is to provide an environmental labelling scheme that will contribute to a sustainable consumption as well as providing a practical tool for consumers to be able to choose environmentally-sound and high quality products. ${ }^{3}$

The participating companies receive a licence and are permitted to sell the products and services with the Swan Label signalling that these are environmentally friendly and that they have fulfilled stringent environmental and climate criteria.

\subsubsection{Fees}

The Swan Label is voluntary for companies to participate in and acquire. However, the companies have to pay fees to get products or services approved and yearly fees based on the sales of those products or services. The fees are harmonised across the Nordic countries and specified later in the report.

\subsubsection{Licence criteria}

To be able to obtain a Swan Label a company's product or service must live up to the criteria defined for the specific product or service. There are currently 65 different groups under which companies can have their products and services approved. An example of a product group is Hand Dishwash Detergents while an example of a service group is Hotels and

${ }^{3}$ Based on http://www.nordic-ecolabel.org/about/ and http://www.ecolabel.dk/da/blomsten-og-svanen/ 
youth hostels. The criteria are described in a very detailed manner in documents available online. 4

A company wanting to carry the Swan Label can apply at the national secretariat in the market where they want to sell Swan labelled products or services. In each of the Nordic countries local national secretariats have the responsibilities of criteria development, licensing, marketing and audits. The company is awarded the Swan Label through a licensing process where licences are granted to products or services that fulfil the criteria.

The licence criteria are developed by experts from the Nordic Ecolabelling organisations. Experts from ministries, environmental organisations, producers, etc. can give their opinion and, thus, indirectly participate in the development of criterias. Before The Nordic Ecolabelling Board finalises the criteria, they are sent out for review, where everybody are able to comment on the criteria and suggest further adjustments. To ensure that Swan labelled products/services are as environmentally friendly as possible the criteria are continuously reviewed and revised every 3-5 years. This is done to take into account product development progress and new scientific discoveries as well as new information about environmental impact. Products or services carrying a Nordic Ecolabel licence must apply and fulfill the new criteria requirements. ${ }^{5}$

\subsection{About the EU Ecolabel}

The EU Ecolabel (also known as the Flower) is the official Ecolabel of the EU countries and was established in 1992 by the European Commission. The purpose of the EU Ecolabel is much like that of the Swan Label: to make it simple for consumers and companies to choose a product or service which is both environmentally friendly and of good quality, as well as to be a driver of environmental awareness and responsibility among producers. As with the Swan Label the EU Ecolabel is easy to recognise and a reliable brand. ${ }^{6}$

A further similarity to the Swan Label is that the participating companies receive a licence and are permitted to sell the products and services with the EU Ecolabel signalling that these are environmentally friendly and that they have fulfilled stringent environmental and climate criteria.

\footnotetext{
${ }^{4} \mathrm{http} / / /$ www.nordic-ecolabel.org/criteria/product-groups/

${ }^{5} \mathrm{http}$ ///www.nordic-ecolabel.org/criteria/the-criteria-process/

${ }^{6} \mathrm{http}: / /$ ec.europa.eu/environment/ecolabel/
} 


\subsubsection{Fees}

Just like the the Swan Label, the EU Ecolabel is voluntary for companies to participate in and acquire. However, the companies have to pay fees to get products or services approved and yearly fees based on the sales of those products or services. The fees are more or less similar across all EU countries and are specified later in the report. ${ }^{7}$ However, there are differences when it comes to implementation since the fees are voluntary for the member states to charge and some countries do not charge them. Furthermore, the conditions for the fees are expected to change in the future. It is expected that the member states will be able to choose between keeping the flat rate fee which is used currently or utilising a fee dependant on the turnover.

\subsubsection{Licence criteria}

The process of acquiring an EU Ecolabel also shares many similarities to the Swan Label's process. There are well-defined product groups within which products and services can become licensed. Currently, 31 different product groups exist. ${ }^{8}$ There is some degree of overlapping between the two ecolabels, but mostly the groups are not the same. The report investigates this overlap further below.

EU based companies apply at the national Competent Body. Applicants outside of the EU apply to a Competent Body of the market where they want to sell their EU Ecolabelled product or service. The Competent Body evaluates applications to award the EU Ecolabel.

The criteria are developed and agreed upon in ad hoc working groups with the participation of stakeholders (NGOs, industry, member states, scientists). Criteria are finally decided by a Committee of national experts from the Member States.

From the raw materials to manufacturing, packaging, distribution and disposal, EU Ecolabel products are evaluated according to the specific criteria document by the Competent Body where the application has been submitted for evaluation to ensure they meet criteria that reduce their environmental impact. ${ }^{9}$

\footnotetext{
${ }^{7}$ Some differences exist which will be explored later in the report.

${ }^{8}$ According to http://www.ecolabel.dk/da/produkter/ / link.aspx?_id=D1BE384444A54415B0417CF318B4E9B7\&_z=z

${ }^{9} \mathrm{http}: / /$ ec.europa.eu/environment/ecolabel/information-and-contacts.html
} 



\section{Methodology}

As described in the introduction, the analysis has three central themes which are analysed using several methodological methods and steps. These are described in further detail in the following:

\section{The positioning and success of the Swan Label and the EU Ecolabel within different product categories}

The first part of the analysis looks closer at the the success and positioning of the two labels within different product groups. This is done through:

- Determining the number of licence holders and trade names within the different product groups of the two labels and across countries.

- Examining the licencees experience and attitude towards the two labels and their motivation for choosing one over the other.

Initially, a mapping is made of the number of licence holders and trade names within and across each country for both of the labels. This will make it possible to see where the two labels have their strongest positions. In particular where the two labels have overlapping product groups it will be interesting to look closer at the differences.

In this connection, as well as in connection with the other parts of the project, DAMVAD has cooperated with Assistant Professor Åke Thidell from Lund University. Åke Thidell has in-depth knowledge of and experience with comparisons of national and international ecolabels (among others the Swan Label) and is contributing to the analysis of the results.

Furthermore, to investigate the licencees experience, attitude and motivation towards the two labels, the analysis draws on two elements. First, DAMVAD is conducting another analysis of the impact of the Swan Label for companies. Through this analysis, 16 interviews have been done with companies across the Nordic countries having the Swan Label. These interviews have been conducted very thoroughly and questions on motivation for acquiring the Swan Label (and not the EU Ecolabel) will be drawn upon in the current analysis. Furthermore, and for this analysis, telephone interviews have been performed with companies only having the EU Ecolabel. Since the analysis of the impact of the Swan Label also covers companies having both labels, the entire sample space is covered: 


\begin{tabular}{lll}
\hline & \\
\hline $\begin{array}{l}\text { Company } x \\
\text { Company } y\end{array}$ & $\mathrm{x}$ & $\mathrm{x}$ \\
\hline
\end{tabular}

Secondly, and to build upon the learning of the interviews, a survey is conducted among the licencees of the Swan Label and the EU Ecolabel in the Nordic countries. The survey looks further into the motivational factors choosing one label over the other, or the reasons for choosing both.

The survey has the following number of answers:

Table 2: The number of answers given in the survey among companies

\begin{tabular}{lc}
\hline Country & Number of answers \\
\hline Denmark & 57 \\
Finland & 36 \\
Iceland & 12 \\
Norway & 44 \\
Sweden & 25 \\
Total & 174 \\
\hline
\end{tabular}

\section{The synergy and positioning between the fee and criteria}

\section{structures of the Swan Label and the EU Ecolabel}

In the second part of the report a comparative analysis is done investigating the key similarities and differences in the fee and criteria structures between the Swan Label and the EU Ecolabel.

Initially, the similarities and differences in types of fees and prices between the two systems are examined. This includes looking closer at the application fees, renewal fees and yearly fees as they are described on the websites of the national ecolabellings secretariats. Furthermore, the types of criteria used in the two systems within the various product categories are investigated and compared focusing on key similarities and differences. 


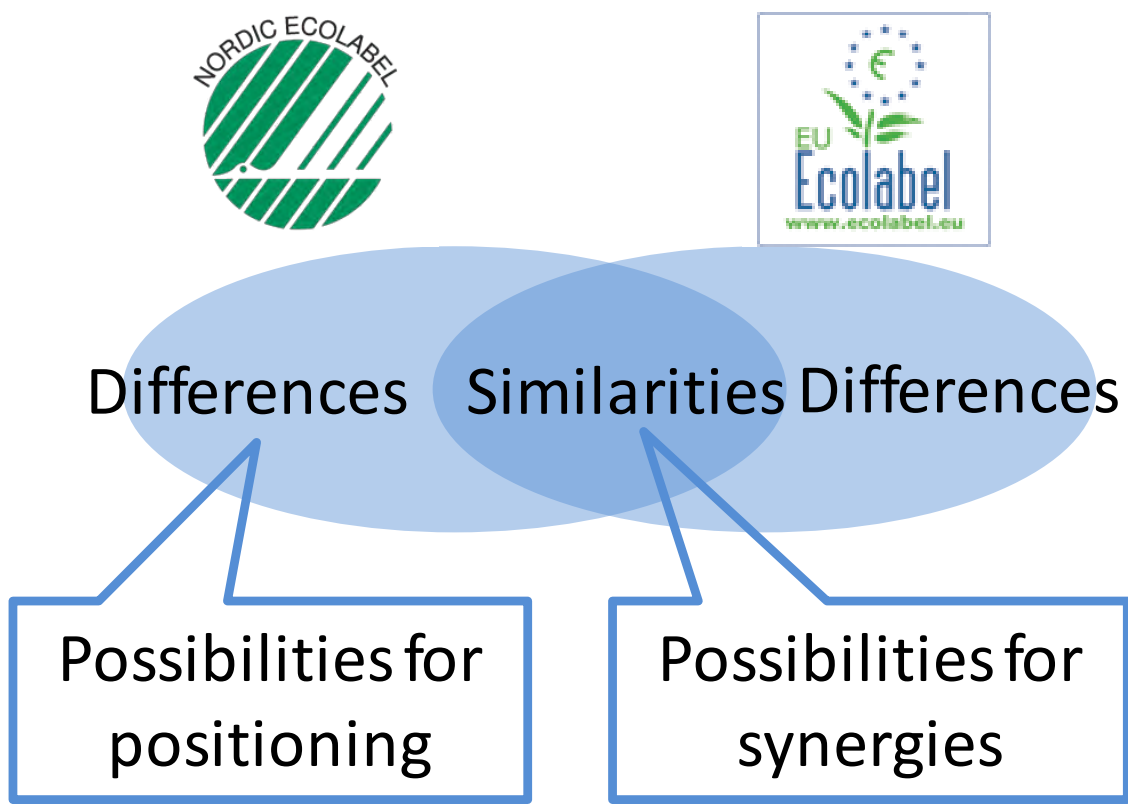

On the basis of this, the consequences and possibilities of these similarities and differences are analysed. Basically, two possibilities for action can be seen: synergies and positioning.

Synergies can be achieved through cooperation on the development and adjustment of criteria which are nearly similar and through the coordination/merging of licence fees so that the two ecolabels become more attractive for exisiting or potential licence holders. The purpose is to minimise the costs and administrative burdens for companies when it comes to areas where there are similarities between the two ecolabels.

With regard to positioning it is a question of whether it is a goal to develop a clear and differentiated profile of the Swan Label towards the EU Ecolabel. If so, a targeted effort towards product categories with a particular interest for the Nordic markets and consumers can be made.

To investigate these topics interviews have been performed with the national ecolabelling secretariats of the five Nordic countries, besides a desk research of the fees and criteria structures. Through the interviews with the ecolabelling secretariats we wish to shed light on the experiences with the two systems and identify possibilities for synergies and positioning between the Swan Label and the EU Ecolabel. 


\section{The experience with co-existence between the EU Ecolabel and other national and regional ecolabels}

In the third part of the analysis, experience with co-existence between other national and regional ecolabels and the EU Ecolabel is examined. In countries outside the Nordics experience exists with co-existence, coordination, synergy and competition between parallel ecolabel systems.

Experience from the following countries is drawn upon by interviewing the environmental secretariats of these countries:

- Austria.

- France.

- Germany.

- The Netherlands.

The interviews focus on five important questions:

1. Which ecolabelling systems exist in the country besides the EU Ecolabel?

2. What are the experiences with coordination/cooperation between these?

3. What are the experiences with competition between these?

4. What do the companies say about parallel ecolabelling systems?

5. Are there any relevant experiences to learn from for the development of the Swan Label?

\subsection{Methodology for the chapter on positioning and success}

The data on licence holders and trade names under the Swan Label and the EU Ecolabel has been collected from the websites of the environmental secretariats of the five Nordic countries. The data collection has been performed in January and February of 2013.

Comparison between the countries has to be done with some degree of carefulness. This is because the countries do not provide the data in the same manner. However, the authors of this report find that the data provides reasonable grounds for comparison.

For the sorting of the data into product groups the two ecolabels' well-defined product groups have been chosen. These official product groups have been used to group the countries' own product groups which on occasion differ from the official ones of the two labels'. This is the case because the national environmental agencies' homepages are 
targeted towards consumers and have adjusted the product groups towards consumer interests. Each product group in each country has been examined and fitted into the correct and official product groups when counting licence holders and trade names.

In cases where national product groups differ from the official product groups it has in some cases been necessary to let the national product group be decisive of the separation of the data. Some official product groups are composed of several national product groups. Example: kitchen towels, napkins and handkerchiefs have all been counted under tissue paper. If a licence holder has trade names under both kitchen towels and napkins, this licence holder has been counted only once. The same case goes for categories such as cosmetics, sanitary products and chemical building products.

\subsubsection{Counting licence holders and trade names}

The number of licence holders corresponds to the number of companies which hold an ecolabelled product or service within a given product group. When looking at licence holders across groups companies are not necessarily unique. This means that if a company has registrered products under two different product groups the company is counted once under each product group.

However, a company can have several trade names registered in the same category. An example is Abena Produktion A/S which has five different types of diapers registered. The company counts as a licence holder once, but with five trade names.

As mentioned above the homepages of the environmental secretariats are often targeted towards consumers so that they can easily find the sought after products. This means e.g. that products in a childrens category can be found again in the category for skin care. When this occurs, the licence holder and trade name has been counted once.

Services have been counted once. When a hotel chain has ten hotels labelled, it counts for 10 licences and 10 trade names.

Some homepages only present a licence holder and not the number of trade names. This is e.g. true for Norway regarding painting companies.

A short description of how the countries present their data is given below: 
- Denmark presents the number of licence holders and trade names directly.

- Finland does not present the number of either directly and the numbers of licence holders and trade names have been found by going through the product groups one by one.

- Iceland presents the data directly.

- Norway presents the number of trade names directly for each product group. The number of licence holders has been found by counting the number of unique companies producing for each category.

- Sweden does not present the number of either directly and the numbers of licence holders and trade names have been found by going through the product groups one by one. 


\section{Positioning and success}

This chapter looks further into the positioning and fields of success of the Swan Label and the EU Ecolabel from a company perspective. Firstly, this is done by presenting the prevalence of the labels across different product categories and across countries. ${ }^{10}$ The second half of the chapter looks deeper into why companies choose to bear an ecolabel, and the motivational factors influencing the choice of one label over the other.

\subsection{Participation of companies across product groups and countries}

The prevalence of the Swan Label and the EU Ecolabel in the Nordic countries is presented in three sections using data on licence holders and trade names. A licence holder is a company having its product or service registered under one of the labels. Each company under each product group has been counted, meaning that a company having one product registered under "washing machines" and one under "washing powder" will be counting for one licence holder under each of the two categories. A trade name is the name of the product or service which has been licensed. Each trade name has been counted, meaning that one company can have several trade names under the same product groups and can have trade names in several countries.

First a closer look is taken at the labels' main product categories measured in two dimensions - number of licence holders and trade names. Next the prevalence of the labels in the different Nordic countries is presented. This is summed up in a comparative section presenting key fields of success and ranking the Nordic countries.

10 The methodology for this chapter can be found in chapter 3 . Sources in the appendix. 


\subsection{The prevalence of the Swan Label}

The following section takes a closer look at the prevalence of the Swan Label, focusing on licence holders, trade names and a ranking of the Nordic countries.

\subsubsection{The Swan Label is strong in certifying services}

Among the Swan Label's largest product categories, counted by number of licence holders, are several services. Six of the fifteen largest product categories are services. Examples are printing companies, hotels and youth hostels, grocery stores, vehicle wash installations, textile services and restaurants. This indicates that service categories are a dominant product type of the Swan Label. The table below gives a detailed view of the Swan Label's 15 largest product categories. The table shows that apart from product categories covering services, cleaning products and furniture are the large product groups.

Table 3: Swan Label certified product categories with most licence holders

\begin{tabular}{|c|c|c|}
\hline Product category & Licence holders & Trade names \\
\hline Printing Companies* ${ }^{11}$ & 475 & 1,322 \\
\hline Hotels and Youth Hostels* & 440 & 440 \\
\hline Supermarket Grocery Stores* & 269 & 269 \\
\hline Cleaning Products & 107 & 1,316 \\
\hline Furniture and Fitments & 100 & 1,180 \\
\hline Vehicle wash installations* & 99 & 99 \\
\hline Cosmetic products & 97 & 2,000 \\
\hline Laundries/ Textile Services* & 66 & 66 \\
\hline Tissue paper & 65 & 1,388 \\
\hline Restaurants* & 58 & 58 \\
\hline Laundry detergents and stain removers & 49 & 640 \\
\hline Toner cartridges & 46 & 5,822 \\
\hline Sanitary Products & 46 & 686 \\
\hline Dishwasher detergents for professional use & 41 & 358 \\
\hline Hand Dishwash Detergents & 37 & 192 \\
\hline
\end{tabular}

*= product group covers a service.

Source: DAMVAD, 2013, based on the websites of the Nordic ecolabelling secretariats.

11 Due to variation in data from the Nordic countries this category contains both a service aspect, e.g. a shop that has printing facilities and companies that produce all kinds of paper products for printing. 
This strong position in services especially comes about when chains of stores decide to become labelled. Thus, when a supermarket chain decides to label all of their stores, all of these stores are counted as licence holders.

Since services have a dominating role they are excluded in the following table to get a closer look at the predominant product groups. Excluding services from the overview the Swan Label's front runner categories of conventional products are cleaning products for household use, furniture and cosmetic products. Also tissue paper, laundry detergents and toner cartridges are large product categories of the Swan Label. Generally the Swan Label's largest product groups are dominated by cleaning products for household use, products for personal hygiene and a few unique categories like furniture, building elements and stoves. The table below gives the detailed view of the 15 largest product categories of the Swan Label excluding product categories containing services.

\begin{tabular}{lrr} 
Table 4: Swan Label certified product categories with most licence holders, services not included \\
\hline Product category & Licence holders & Trade names \\
\hline Cleaning Products & 107 & 1,316 \\
Furniture and fitments & 100 & 1,180 \\
Cosmetic products & 97 & 2,000 \\
Tissue paper & 65 & 1,388 \\
Laundry detergents and stain removers & 49 & 640 \\
Toner cartridges & 46 & 5,822 \\
Sanitary Products & 46 & 686 \\
Dishwasher detergents for professional use & 41 & 358 \\
Hand Dishwash Detergents & 37 & 192 \\
Car and boat care products & 36 & 314 \\
Fabric cleaning products containing microfibres & 31 & 278 \\
Filmforming floor care products & 31 & 160 \\
Stoves & 27 & 850 \\
Chemical building products & 25 & 277 \\
Dishwasher detergents & 25 & 198 \\
\hline
\end{tabular}

Source: DAMVAD, 2013, based on the websites of the Nordic ecolabelling secretariats.

\subsubsection{Cosmetics, tissue paper and toner cartridges hugely represented among trade names}

Toner cartridges certified by the Swan Label is the largest product group when counted by number of trade names. The result is interesting but it should be taken into consideration that this is influenced by particular circumstances of toner cartridge as a product group. It is a market characterised by a large number of actors each producing a significant amount of models, each again using many different colour cartridges.

Cosmetic products and a variety of cleaning and paper products, e.g. laundry detergents, dishwasher detergents, as well as paper products, e.g. 
tissue paper, sanitary products, copy and printing paper, are, furthermore larger product groups of the Swan Label when looking at trade names.

Moreover, a considerable amount of "technical" products are Swan Labelled, e.g. imaging equipment and audiovisual equipment.12 The following table sums this up by showing the product groups with the highest amount of trade names.

Table 5: The Swan Label's product categories sorted by trade names

\begin{tabular}{|c|c|c|}
\hline Product category & Licence holders & Trade names \\
\hline Toner cartridges & 46 & 5,822 \\
\hline Cosmetic products & 97 & 2,000 \\
\hline Tissue paper & 65 & 1,388 \\
\hline Printing Companies* & 475 & 1,322 \\
\hline Cleaning Products & 107 & 1,316 \\
\hline Furniture and fitments & 100 & 1,180 \\
\hline Stoves & 27 & 850 \\
\hline Sanitary Products & 46 & 686 \\
\hline Imaging equipment & 16 & 670 \\
\hline Laundry detergents/stain removers & 49 & 640 \\
\hline Copy and printing paper & 20 & 566 \\
\hline Indoor paints and varnishes & 22 & 535 \\
\hline Hotels and youth hostels* & 440 & 440 \\
\hline Dishwasher detergents for professional use & 41 & 358 \\
\hline Audiovisual equipment & 6 & 354 \\
\hline
\end{tabular}

*= Product group covers a service.

Source: DAMVAD, 2013, based on the websites of the Nordic ecolabelling secretariats.

\subsubsection{Swan Label homogeneity across the Nordic countries with lead positions of Sweden and Denmark}

Generally, the Nordic countries are quite homogenous with respect to the amount of the Swan Label licence holders and trade names. Sweden and Denmark share lead positions closely followed by Norway and Finland. Iceland takes a special position with very few licence holders and trade names which can be explained by the small market. This general observation, however, is qualified by some interesting findings of the comparative mapping of the Nordic countries.

Sweden takes the lead position when ranking by number of licence holders. Sweden has more than twice as many licence holders than the second ranked country, Denmark. This lead position seems to be closely tied to product categories containing services. Swedish licences for hotels and youth hostels, restaurants and supermarkets sum up to 549

12 These categories contain products like scanners, copying devices, screens etc. 
compared to Denmark's 30 licences across these three product categories. In particular, this has to do with certain chains of stores becoming labelled in Sweden. Further, excluding services, the homogeneity of the Nordic countries visualises with less than 100 licence holders between the top position of Denmark and lowest position of Finland (excluding Iceland).

Denmark stands out when ranking the Nordic countries by trade names having more than 2,000 trade names more than Sweden, being secondly ranked. A qualitative look at product categories points to a high concentration of trade names in product categories like cosmetics, cleaning products, tissue paper and laundry detergent. Apart from this front runner position Norway, Sweden and Finland show similarities across the countries. The following table gives the detailed overview of the representation in the Nordic countries.

Table 6: Countries ranked by number of Swan Label licence holders and trade names

\begin{tabular}{llrr}
\hline Ranking mode & Country & Licence holders & Trade names \\
\hline By number of licence holders $^{13}$ & Sweden & 1,128 & 5,316 \\
& Denmark & 558 & 7,682 \\
& Norway & 515 & 4,868 \\
& Finland & 319 & 4,397 \\
& Iceland & 24 & 24 \\
By number of licence holders, services excluded & Denmark & 336 & 6,613 \\
& Sweden & 287 & 4,475 \\
& Norway & 244 & 4,597 \\
& Finland & 213 & 4,291 \\
By number of trade names ${ }^{14}$ & Iceland & 1 & 1 \\
& & & 7,682 \\
& Denmark & 558 & 5,316 \\
& Sweden & 1,128 & 4,868 \\
& Norway & 515 & 24 \\
\hline
\end{tabular}

Source: DAMVAD, 2013, based on the websites of the Nordic ecolabelling secretariats.

\footnotetext{
13 The number of licence holders is counted by adding up the number of licence holders in each product category in each country. In this way a licence holder can be counted more than once if 1 ) the licence holder has licences in more than one product category. E.g. if a company has a licence to both Cosmetic products and Sanitary products it will be counted twice. 2) the licence holder has licences in more than one Nordic cou ntry. Furthermore each service unit counts for one licence holder.

14 The method used aims at counting unique trade names. However numbers are vulnerable to the national ecolabel secretariats differences in data enumeration.
} 


\subsection{The prevalence of the EU Ecolabel}

The following section takes a closer look at the prevalence of the EU Ecolabel, focusing on licence holders, trade names and a ranking of the Nordic countries.

\subsubsection{The EU Ecolabel mostly certifies licence holders of textiles, painting and campsite services}

Ranking the EU Ecolabel's product categories by the number of licence holders first of all shows that a limited amount of licence holders of the EU Ecolabel exist within the Nordic countries compared to the Swan Label. The table below shows that only three product categories have more than 10 licence holders. "Textiles" is the product category with far most licence holders followed by indoor paints and varnishes and campsite services.

Table 7: EU Ecolabel product categories with most licence holders

\begin{tabular}{lrr}
\hline Product category & Licence holders & Trade names \\
\hline Textiles & 30 & 397 \\
Indoor Paints and varnishes & 18 & 311 \\
Campsite services* & 13 & 13 \\
Tissue paper & 8 & 152 \\
All cleaning products & 8 & 62 \\
Copy and graphic paper & 7 & 315 \\
Soaps, shampoos and hair conditioners & 7 & 33 \\
Tourist accommodation services* & 7 \\
Detergents for dishwashers & 7 & 21 \\
Laundry detergents & 4 & 16 \\
Outdoor Paints and varnishes & 4 & 94 \\
Footwear & 3 & 39 \\
Mattresses & 2 & 48 \\
Hard floor coverings & 2 & 42 \\
Televisions & 1 & 29 \\
Lubricants & 1 & 8 \\
Growing media and soil improvers (excluding soil) & 1 & 2 \\
Hand dishwashing detergents & 1 & 1 \\
\hline
\end{tabular}

*=services.

Source: DAMVAD, 2013, based on the websites of the Nordic ecolabelling secretariats. 


\subsubsection{Textiles, painting and paper hold the most trade names under the EU Ecolabel}

Measured by trade names, textiles is again the top product group of the EU Ecolabel in the Nordic countries. Other product groups in the top layer are copy and graphic paper, indoor painting and tissue paper. Product types that were in the lowest part of the top- 15 when sorting by licence holders, e.g. outdoor paint and varnishes and mattresses, are now situated in the upper half.

\begin{tabular}{|c|c|c|}
\hline Product category & Licence holders & Trade names \\
\hline Textiles & 30 & 397 \\
\hline Copy and graphic paper & 7 & 315 \\
\hline Indoor Paints and varnishes & 18 & 311 \\
\hline Tissue paper & 8 & 152 \\
\hline Outdoor Paints and varnishes & 3 & 94 \\
\hline All cleaning products & 8 & 62 \\
\hline Mattresses & 1 & 48 \\
\hline Hard floor coverings & 1 & 42 \\
\hline Footwear & 2 & 39 \\
\hline Soaps, shampoos and hair conditioners & 7 & 33 \\
\hline Televisions & 1 & 29 \\
\hline Detergents for dishwashers & 4 & 21 \\
\hline Laundry detergents & 4 & 16 \\
\hline Campsite services* & 13 & 13 \\
\hline Lubricants & 1 & 8 \\
\hline
\end{tabular}

*=services.

Source: DAMVAD, 2013, based on the websites of the Nordic ecolabelling secretariats.

\subsubsection{Distinct Nordic differences in the prevalence of the EU Ecolabel}

Overall, the Nordic countries are distributed gradually with clear intervals between the countries resulting in a relatively clear ranking. Denmark holds the top position with most licence holders and trade names. Sweden holds the second position with half the amount of licence holders and trade names as Denmark, while Finland takes third position. Norway holds the lowest position with only four licence holders. As mentioned earlier, Iceland has not introduced the EU Ecolabel and cannot be found in the table below. 
Table 9: Countries ranked by number of EU Ecolabel trade names and licence holders

\begin{tabular}{lrr}
\hline Country & Licence holders & Trade names \\
\hline Denmark & 71 & 863 \\
Sweden & 29 & 426 \\
Finland & 13 & 295 \\
Norway & 4 & 7 \\
\hline
\end{tabular}

Source: DAMVAD, 2013, based on the websites of the Nordic ecolabelling secretariats.

\subsection{Strengths of the Swan Label and the EU Ecolabel}

This section sums up the results from above by comparing the labels' positions across product categories and across the Nordic countries.

The results presented above and indicated below in the table clearly underline the Swan Label's dominant position in the Nordic countries. However, the method of reporting and, in turn, counting the licence holders and trade names must be taken into consideration. If a company e.g. has the same product Swan licensed in Sweden and in Denmark it will count as a licence holder in both countries and a trade name in both countries. The way the EU Ecolabel is reported means that licence holders are only counted once. A further issue is that no reliable database of EU Ecolabel products in the Nordic countries exists. As such, products which are EU ecolabelled in e.g. Germany can be sold in one of the Nordic countries without being counted in the numbers above. The Nordic ecolabelling secretariats are currently working towards a common Nordic database containing a reliable number of Swan licences and trade names.

\subsubsection{Product-specific strengths}

Focusing exclusively on product categories containing services it is clear that the Swan Label is well-positioned within a broad range of service categories; e.g. tourist accommodation, printing facilities and supermarkets. Within services, the highest ranked product category of the EU Ecolabel is campsite services.

Extending the analysis to conventional products highlights certain strong positions of the labels. The EU Ecolabel is best positioned within textiles, painting and paper products of tissue and copy/graphic. The Swan Label's strongest positions are within household cleaning products, cosmetics, tissue paper, furniture and toner cartridges. The table below shows this. 
Table 10: Comparative strengths of the Swan Label and EU Ecolabel across product categories in the Nordic countries

\begin{tabular}{|c|c|c|}
\hline Ranking variable & The Swan Label & The EU Ecolabel \\
\hline \multirow[t]{5}{*}{ Licence holder } & 1. Printing Companies* $(475)^{15}$ & 1. Textiles (30) \\
\hline & 2. Hotels and Youth Hostels* $(440)$ & 2. Indoor Paint and varnishes (18) \\
\hline & 3. Supermarket Grocery Stores*(269) & 3. Campsite services* (13) \\
\hline & 4. Cleaning products (107) & 4. Tissue paper (8) \\
\hline & 5. Furniture and fitments (100) & 5. All cleaning products (8) \\
\hline \multirow{5}{*}{$\begin{array}{l}\text { Licence holder } \\
\text { excluding services }\end{array}$} & 1. Cleaning products (107) & 1. Textiles (30) \\
\hline & 2. Furniture and fitments (100) & 2. Indoor Paint and varnishes (18) \\
\hline & 3. Cosmetic products (97) & 3. Tissue paper (8) \\
\hline & 4. Tissue paper (65) & 4. All cleaning products (8) \\
\hline & 5. Laundry detergents and stain removers (49) & 5. Copy and graphic paper (7) \\
\hline \multirow[t]{5}{*}{ Trade names } & 1. Toner cartridge $(5,822)$ & 1. Textiles (397) \\
\hline & 2. Cosmetic products $(2,000)$ & 2. Copy and graphic paper (315) \\
\hline & 3. Tissue paper $(1,388)$ & 3. Indoor paint and varnishes (311) \\
\hline & 4. Printing companies $*(1,322)$ & 4. Tissue paper (152) \\
\hline & 5. Cleaning products $(1,316)$ & 5. Outdoor paint and varnishes (94) \\
\hline
\end{tabular}

Source: DAMVAD 2013, based on the websites of the Nordic ecolabelling secretariats.

\subsubsection{Country-specific strenghts}

There is a clear difference in the prevalence of the two ecolabels across the Nordic countries. Focusing on the Swan Label and ranking by licence holders, Sweden is a frontrunner followed by an almost even distribution of Denmark and Norway then Finland and last Iceland. Ranked by trade names, Denmark is in front followed by the rest of the Nordic countries that hold quite similar numbers of trade names.

The EU Ecolabel's distribution across the Nordic countries is much more hierarchical with Denmark having the largest amounts of licence holders and trade names, followed by Sweden, Finland and with the fewest in Norway.

A number of reasons are relevant when looking at why there are inter-country differences. First of all, Iceland has a smaller number of Swan Label licence holders and trade names mainly because of the smaller market. Secondly, the reason for why Denmark is a front-runner when it comes to the EU Ecolabel comes from a strong focus from the authorities at an early stage to attract the textile industry to carry the label. Furthermore, according to a representative from the Swan group under the Nordic Council of Ministers, Denmark utilises a different way

\footnotetext{
15 Due to variation in data from the Nordic countries this category contains both a service aspect, e.g. a shop that has printing facilities and companies that produce all kinds of paper products for printing.
} 
of counting the products and licences, resulting in a higher number of products/licences under both labels. Finally, Denmark provides significant funding through the yearly financial law (Finansloven), making it possible to market both of the labels more significantly.

\subsection{The reasons for acquiring an ecolabel}

To better understand the companies' choices of ecolabels and why it is important for them to carry one a survey among companies in the Nordic countries carrying the Swan Label, the EU Ecolabel or both has been conducted. The survey looks closer at why the ecolabels are chosen and why one label is chosen over the other.

Results reveal, not surprisingly when taking the above into consideration, that only few companies have chosen the EU Ecolabel. The results for the EU Ecolabel should, thus, be analysed with caution.

\subsubsection{The Swan Label is acquired for the green profile - the EU Ecolabel to stand out from competitors}

Companies mostly acquire the Swan Label to sustain or obtain a green profile or because customers demand it. The EU Ecolabel, however, is in most cases acquired to be able to distinguish products or services from competitors'. The figure below shows this.

$65 \%$ of the companies carrying the Swan Label do so because the Swan Label is part of the company's green profile while $62 \%$ want to achieve a better/more green image. 57\% say customers demand the Swan Label while $52 \%$ wanted to introduce/achieve environmental improvements in their production or the company in general.

Looking at the EU Ecolabel holders 70\% indicate that they acquired the label to be able to distinguish from competitors while $56 \%$ acquired the label to achieve a better/more green image and likewise, 56\% say it is a part of the company's green profile. 
Figure 2: Reasons for choosing the Swan Label/the EU Ecolabel

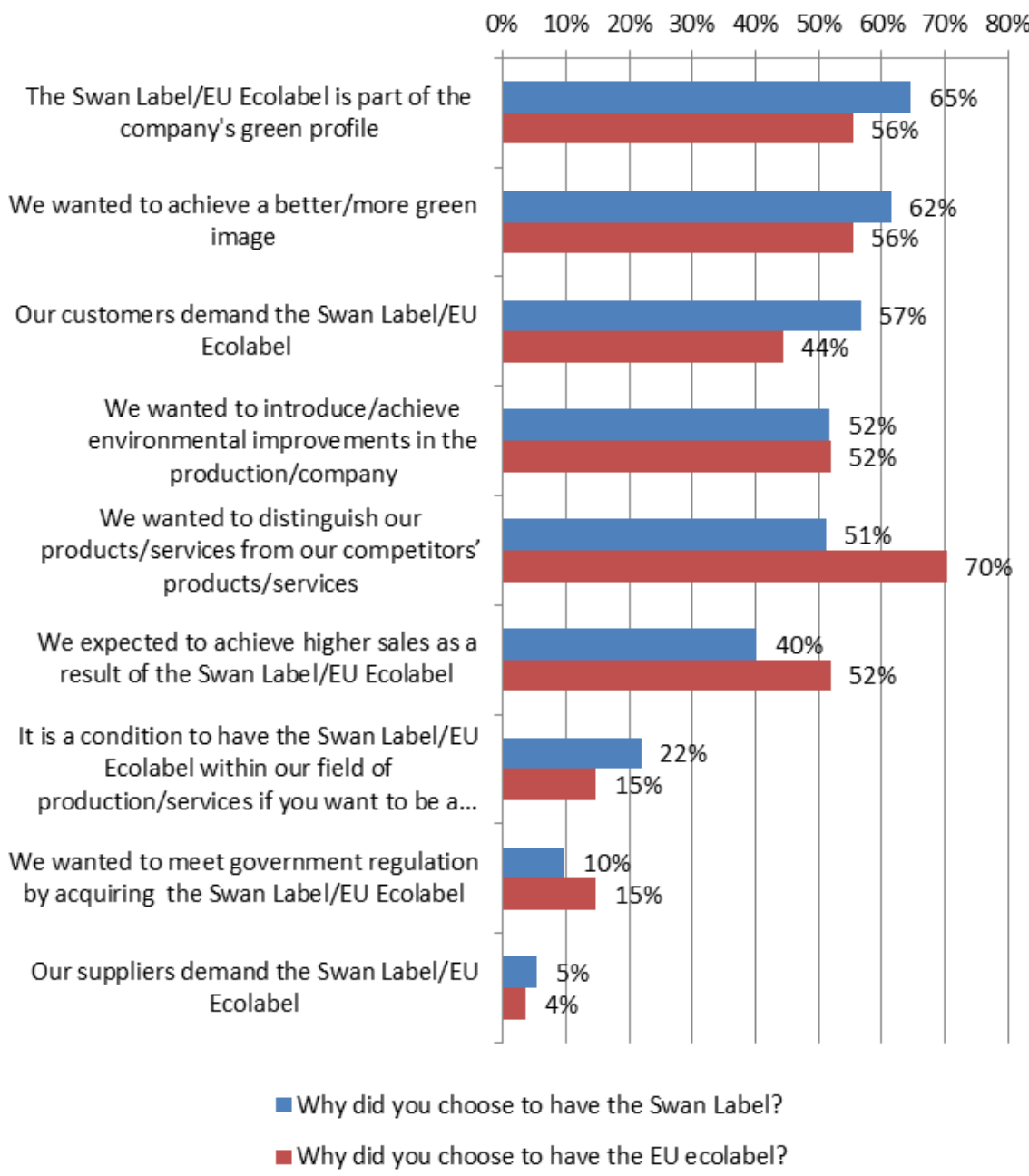

Source: DAMVAD 2013, based on a survey conducted for the analysis. Note: Swan Label: $n=164$, EU Ecolabel: $n=27$.

\subsubsection{The Swan Label is a market standard}

The companies carrying the Swan Label do so because it is more known on the markets on which they operate and because the Swan Label has become a market standard - the customers demand Swan labelled products and services. The following figure shows this.

As it can be seen $42 \%$ of the Swan Label carrying companies indicate that the Swan Label is more known than the EU Ecolabel among their customers and $31 \%$ say that the Swan Label is a demand from the market. 
However, 33\% of the companies carrying the Swan Label also indicate that it is not possible within their field of production/services to acquire the EU Ecolabel. This does not necessarily mean, however, that they would have chosen the EU Ecolabel had they had the possibility.

\section{Figure 3: Reasons for choosing the Swan Label over the EU Ecolabel}

$0 \% \quad 5 \% \quad 10 \% \quad 15 \% \quad 20 \% \quad 25 \% \quad 30 \% \quad 35 \%$ 40\% $45 \%$

The Swan Label is more known than the EU ecolabel among customers for our product(s)

It is not possible within our field of production/services to acquire the EU ecolabel

The the Swan Label is required by the market/markets we operate in

The Swan Label was easier for us to acquire than the EU ecolabel because it is easier to fulfill the criteria

The Swan Label (and not the EU ecolabel) is a requirement from our suppliers

The Swan Label costs less for us to acquire than the EU ecolabel

We have not heard of the EU ecolabel

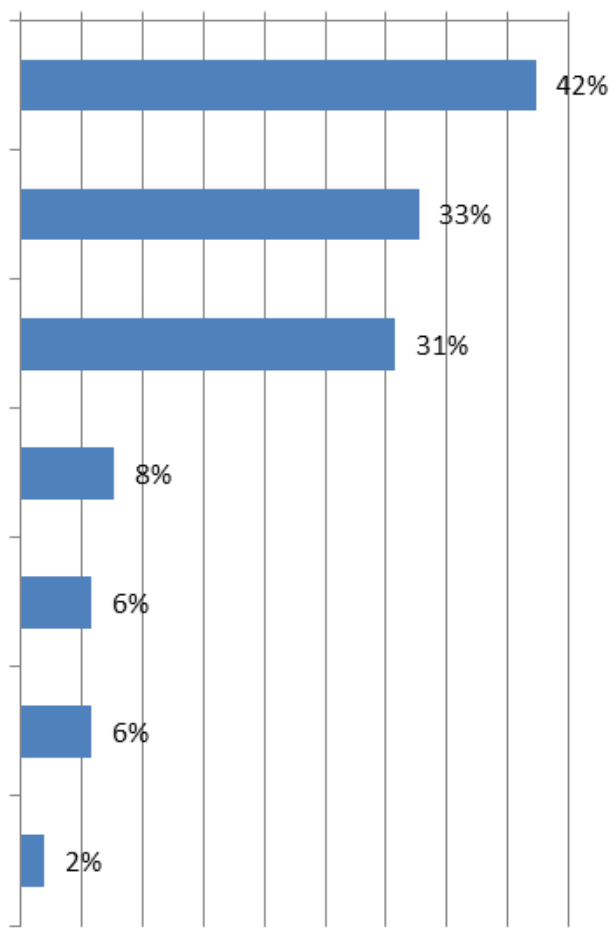

Why did you get the Swan Label rather than the EU ecolabel?

Source: DAMVAD 2013, based on a survey conducted for the analysis.

Note: Swan Label: $n=52$. 


\subsubsection{The EU Ecolabel is chosen among exporting companies}

Companies acquiring the EU Ecolabel most often do so because they are present on markets outside of the Nordic countries where the Swan Label is less or not known among consumers. This is the dominant conclusion from companies interviewed and surveyed having only the EU Ecolabel. ${ }^{16}$

Moreover, some companies carry products or services where the Swan Label is not applicable or where the EU Ecolabel is the dominant ecolabel. On such areas, the EU Ecolabel is either the only other possibility for demonstrating environmental awareness or the logical choice if the company does not want/need to carry two labels.

\subsection{The Swan Label is well-known among consumers}

The Swan Label is a well-known ecolabel among consumers in the Nordic countries. Between 77 and $96 \%$ of the population (between 15 and 74 of age), recognise the Swan Label (YouGov, 2013). The table below compares the awareness of the Swan Label and the EU Ecolabel across the Nordic countries.

When it comes to the consumers' familiarity with the Swan Label, Sweden stands out with $96 \%$ recognising the label followed by Norway with $89 \%$. Iceland has the lowest level of awareness with $77 \%$ of Icelandic consumers being familiar with the Swan Label.

The EU Ecolabel on the other hand does not in general share the same recognisability as the Swan Label. When confronted with the EU Ecolabel logo, only $20 \%$ of the Nordic consumers recognise the label (YouGov, 2013) (in 2010 however, the logo changed in appearance, which still seems to affect the recognisability). If you compare the Nordic countries in relation to the EU Ecolabel, Denmark takes the lead with $35 \%$ recognising the EU Ecolabel, followed by Finalnd with $20 \%$ and Sweden with $17 \%$.

The table confirms the findings from above showing the higher popularity, awareness and dissemination of the Swan Label.

\footnotetext{
${ }^{16}$ Due to having only few answers from companies with only the EU Ecolabel, interviews have been performed with such companies as a supplement to the survey.
} 
Table 11: Awareness of the ecolables among consumers

\begin{tabular}{lcc}
\hline Country & Swan Label & EU Ecolabal \\
\hline Denmark & $88 \%$ & $35 \%$ \\
Finland & $88 \%$ & $20 \%$ \\
Iceland & $77 \%$ & $16 \%$ \\
Norway & $89 \%$ & $11 \%$ \\
Sweden & $96 \%$ & $17 \%$ \\
Average across the Nordics & $91 \%$ & $20 \%$ \\
\hline
\end{tabular}

Source: YouGov, Jan 2013, “Miljømerking - Nordisk forbrukerundersøkelse 2013.” 


\section{Comparing the fee structures}

In this chapter, the differences in fee structures between the Swan Label and the EU Ecolabel are examined. The chapter distinguishes between application/renewal fees and the annual fees, which companies pay for the licences. Furthermore, examples are given of how the final costs for the companies vary concerning their total turnover and size for the two ecolabels.

All fees mentioned in this chapter are exclusive of VAT.

\subsection{Differences in the application, renewal and extension fees}

When comparing the fee structures between the Swan Label and the EU Ecolabel it is necessary to distinguish between the following types of fees:

\section{Box 1: Fees for the ecolabels}

- Application fee: the application fee covers administrative expenses when a company applies for an ecolabel, when renewing a licence following a criteria revision or when altering a licence.

- Extension fee: the extension fee is paid when the company wants to extend the scope of the licence to more products and/or amend the composition or production of the licensed products. The amount depends on the scope of the amendment/extension.

Source: Based on the websites of the ecolabelling secretariats of the Nordic countries. 


\subsubsection{Fees of the Swan Label}

In 2010, all member countries introduced the same fee structure as seen in the table below.

Today, there are some minor differences across the five countries - in Sweden for instance the application fee is around EUR 2,370 compared to EUR 1,810 in Iceland. The differences are mostly due to volatile exchange rates. Micro enterprises (MIE) ${ }^{17}$ are granted a $50 \%$ discount on the application and renewal fees.

The Swan Label extension fee is dependent on the amount of work the national ecolabelling secretariats has to carry out. The extension fee is on average EUR 270 for $1 / 2$ day of work, EUR 550 for one day of work, and EUR 1,100 for more than one day of work. In Iceland, however, there is a fixed fee no matter the amount of hours spent on the extension work whereas the extension fee is based on an hourly rate in Finland.

Table 12: Fees of the Swan Label

\begin{tabular}{llll}
\hline Type of enterprise & Application fee & Renewal fee & Extension fee \\
\hline MIE $^{18}$ & EUR 1,000 & EUR 500 & EUR 270 for $1 / 2$ day, EUR 550 for 1 day, \\
All other enterprises & EUR 2,000 & EUR 1,000 & EUR 1,100 for more than 1 day* \\
\hline
\end{tabular}

Source: Based on the websites of the ecolabelling secretariats of the Nordic countries. * In Iceland the fee is fixed no matter the hours spent. In Finland an hourly rate apply.

\subsubsection{Fees of the EU Ecolabel}

As the costs of running the EU Ecolabel vary slightly between Competent Bodies in the European countries and from one product to another, fees vary accordingly. The table below shows the estimated variation in application/renewal fees. The renewal fee for a company is the same as the application fee.

As the table shows, micro enterprises, SME's and enterprises from developing countries are able to receive a reduction in both the application/renewal fee and the annual fee. The application fee for applicants registered under the Community eco-management and audit scheme

17 Definition of sizes of enterprises by the Commission Recommendation 2003/361/EC of 6 May 2003 (OJ L 124, 20.5.2003, p. 36)

18 MIE $=$ Micro enterprises, SME $=$ Small and Medium sized enterprises 
(EMAS) may also be reduced by $30 \%$ or by $15 \%$ for enterprises certified under the ISO 14001 standard. ${ }^{19}$

The extension fee is fixed and enterprises pay EUR 115 per hour but not exceeding the application fee.

Table 13: Fees of the EU Ecolabel

\begin{tabular}{lll}
\hline Type of enterprise & Application/renewal fee & Extension fee \\
\hline MIE & EUR 200-350 & EUR 115 per hour, \\
nME and enterprises from developing countries & EUR 200-600 & application fee \\
All other enterprises & EUR 200-2,000 & \\
\hline
\end{tabular}

Source: Based on the EU, EU-Ecolabel wesite. ${ }^{20}$

The text box below shows an example of the EU Ecolabel fees in Denmark:

\section{Box 2: Fees of the EU Ecolabel}

The application and renewal fee for large enterprises in Denmark is currently EUR 1,200, EUR 600 for SME's/enterprises in developing countries and EUR 350 for micro enterprises.

Source: Based on the Danish ecolabelling secretariate website. ${ }^{21}$

\subsubsection{Comparing the fees}

In general, the EU Ecolabel application fee is lower than that of the Swan Label. For micro enterprises, the maximum EU Ecolabel application fee is currently around $2 / 3$ of the cost of the Swan Label's application fee. The application fee differs with EUR 800 for large enterprises but may become the same (when the amendment is adopted). The EU Ecolabel renewal fee is lower than that of the Swan Label fee - with the exception of the renewal fee for large enterprises, where the Swan Label is less costly.

Concerning the extension fee, the fee structure also differs between the two ecolabels. As mentioned above, the extension fee for the EU Ecolabel is based on an hourly rate compared to a working day rate for the Swan Label (with the exception of Finland). This means that if the extension

${ }^{19} \mathrm{Cf}$. Amendment Annex III to Regulation (EC) No 66/2010 of the European Parliament of the Council on the EU Ecolabel. At present, the discount is $20 \%$ for both types of enterprises.

${ }^{20} \mathrm{~A}$ developing country is a country on the OECD Development Assistance Committee list of countries receiving development aid.

${ }^{21}$ http://www.ecolabel.dk/da/in-english/what-does-an-ecolabel-cost/eu-ecolabel/ 
process for the EU Ecolabel takes more than two hours, the costs are higher than paying for $1 / 2$ working day for an extension of the Swan Label.

The calculation examples below show the differences in fees when applying, renewing or extending an ecolabel licence.

The examples illustrate the largest differences between the fees. Since the EU Ecolabel application fee varies between countries and depends on the new amendment, two examples of the differences in the application and renewal fees are given:

Table 14: Examples of differences in the fees

Application fee

Renewal fee

Extension fee
Ex 1: A large enterprise pays around EUR 2,000 when applying for the Swan Label compared to EUR 1200 for the EU Ecolabel (current price structure). The difference in cost is EUR +800

Ex 2: A large enterprise pays around EUR 2,000 when applying for the Swan Label compared to EUR 2,000 for the EU Ecolabel (new price structure).

The difference in cost is EUR 0.00

Ex 1: A micro enterprise pays around EUR 500 when renewing its Swan Label licence while paying EUR 350 for renewing the EU Ecolabel licence (current and new price structure).

The difference in cost is EUR +150

Ex 2: A large enterprise pays around EUR 1,000 when renewing its Swan Label licence while paying EUR 2,000 for renewing the EU Ecolabel license (new price structure). The difference in cost is EUR $-1,000$

An enterprise pays EUR 270 for $1 / 2$ working day ( 4 hours) when extending/amending the Swan Label licence compared to EUR 460 for the EU Ecolabel.

The difference in cost is EUR 210

Source: Calculations based on the websites of the ecolabelling secretariats of the Nordic countries.

\subsection{Differences in the annual licence fees}

The annual fees are defined as:

\section{Box 3: Annual fees}

The annual licence fee: entitles the company to use the ecolabel on its product and in marketing material.

Source: Based on the websites of the ecolabelling secretariats of the Nordic countries 


\subsubsection{The Swan Label's annual licence fee}

The annual licence fee for the Swan Label is based on the company's annual turnover of Swan labelled products. The fee varies from one product group to another - however, for most products the licence fee is $0.3 \%$ of the annual turnover of Swan labelled products and $0.15 \%$ of the annual turnover for services and bulk goods. ${ }^{22}$

There is always a minimum fee payable and for most product groups there is also a maximum fee - again depending on the type of product or service. Iceland is an exception since there is no minimum fee and the maximum fee is EUR 3,395, which is around $1 / 10$ of the maximum fee in the other Nordic countries. It is also worth noticing that the maximum fee in the other Nordic countries varies.

If a company has been granted a licence to use the Swan Label in one Nordic country it applies in the other countries as well. The company needs to register the licence in the countries where it wishes to use it. The registration is free of charge but the company must pay an annual licence fee in the country or countries in which it wants to register the licence.

To make procedures easier a pan-Nordic fee system is currently being developed which will automate registration of licences in all the Nordic countries. Also, fees will be harmonised and are already now identical for many product groups. In the future the licence fee will be calculated based on the total turnover of Swan labelled products in the entire Nordic market. Nordic fees will replace national fees as revised criteria are being introduced for individual product groups.

\subsubsection{The EU Ecolabel's annual licence fee}

Similar to the EU Ecolabel regulations regarding the application and renewal fees, the annual licence fee also varies within the EU-member states. Micro enterprises, SME's, and enterprises operating in developing countries are able to get a reduction in the annual licence fees if the member countries operate with a fixed annual fee. However, with the Amendment Annex III to Regulation (EC) No 66/2010 of the European Parliament of the Council on the EU Ecolabel, the annual fee may also be paid as a percentage of the annual sales like the Swan Label fee structure.

The table below shows the EU Ecolabel fee options:

\footnotetext{
22 In Finland the fee is $0.3 \%$ of the annual turnover for both products and services. Turnovers up to EUR 20 mio. Should the turnover exceed this amount, a licence fee of $0.05 \%$ of the turnover will be charged.
} 
Table 15: Variation in EU Ecolabel annual fees

\begin{tabular}{lrr}
\hline Type of enterprise & Fixed fee $^{23}$ & Percentage fee $^{24}$ \\
\hline MIE $^{25}$ & Max EUR 350 & $\begin{array}{r}0.15 \% \text { of the } \\
\text { annual sale for } \\
\text { products and } \\
\text { services }\end{array}$ \\
SME and enterprises from developing countries & Max EUR 750 & Max EUR 1,500
\end{tabular}

Source: Based on the websites of the ecolabelling secretariats of the Nordic countries and the EU, EU-Ecolabel website. ${ }^{27}$

If a company has been granted a licence to carry the EU Ecolabel in one EU member state it applies in all EU member countries. During the application process, the company must state in which countries the products or services are to be sold.

\subsubsection{Comparing the annual licence fees}

The table below shows the differences in the annual fees between the two ecolabels for a cleaning product (product) and a hotel (service). The EU Ecolabel abbreviations are: MIE $=$ micro enterprise, $\mathrm{SME}=$ Small and medium sized enterprises, and $\mathrm{BE}=$ big enterprises.

In general, the maximum EU Ecolabel annual fee for products is lower than the Swan Label maximum fee - independent of the EU Ecolabel fee structure. For services, the EU Ecolabel is less expensive under the fixed fee system (current price structure), and similar (0.15\%) under the new price structure. However, the maximum EU Ecolabel annual fee of 25,000 (for products and services) is typically lower than for Swan labelled products but higher than for Swan labelled services.

\footnotetext{
23 The annual fixed licence fee is the same for both products and services.

24 Micro enterprises, SME's or applicants from developing countries are entitled to a $25 \%$ reduction in the annual fee.

25 MIE $=$ Micro enterprises, SME $=$ Small and Medium sized enterprises.

26 The maximum fee is EUR 25,000 per product/service group per applicant.

${ }^{27}$ A developing country is a country on the OECD Development Assistance Committee list of countries receiving development aid.
} 
Table 16: Differences in annual fees between the EU Ecolabel and Swan Ecolabel for products and services

\begin{tabular}{|c|c|c|c|c|}
\hline Type & $\begin{array}{l}\text { EU Ecolabel, fixed } \\
\text { (Max fee) }\end{array}$ & $\begin{array}{l}\text { EU Ecolabel, } \\
\text { percentage }\end{array}$ & Swan Ecolabel* & $\begin{array}{l}\text { Example, product groups, } \\
\text { Swan Label }\end{array}$ \\
\hline \multicolumn{5}{|l|}{ Iceland } \\
\hline Products & - & $\begin{array}{l}0.15 \% \text { of } \\
\text { annual sales. } \\
\text { Max = EUR 25,000 }\end{array}$ & $\begin{array}{l}\text { Most products }= \\
0.3 \% \text { of annual sales }\end{array}$ & Max = EUR 3,395 \\
\hline Services & - & $\begin{array}{l}0.15 \% \text { of } \\
\text { annual sales. } \\
\text { Max = EUR } 25,000\end{array}$ & $\begin{array}{l}\text { Most services }= \\
0.15 \% \text { of annual sales }\end{array}$ & Max= EUR 3,395 \\
\hline \multicolumn{5}{|l|}{ Denmark } \\
\hline Products & $\begin{array}{l}\text { MIE }=E U R 350 \\
S M E=E U R 750 \\
B E=E U R 1,500\end{array}$ & $\begin{array}{l}0.15 \% \text { of } \\
\text { annual sales. } \\
\text { Max = EUR 25,000 }\end{array}$ & $\begin{array}{l}\text { Most products }= \\
0.3 \% \text { of annual sales }\end{array}$ & $\begin{array}{l}\text { Min }=\text { EUR } 1,500 \text { per year } \\
\text { Max }=\text { EUR 33,350 per year }\end{array}$ \\
\hline $\begin{array}{l}\text { Services/ } \\
\text { bulk goods }\end{array}$ & $\begin{array}{l}\text { MIE }=E U R 350 \\
S M E=E U R 750 \\
B E=E U R 1,500\end{array}$ & $\begin{array}{l}0.15 \% \text { of } \\
\text { annual sales. } \\
\text { Max = EUR 25,000 }\end{array}$ & $\begin{array}{l}\text { Most services }= \\
0.15 \% \text { of annual sales }\end{array}$ & $\begin{array}{l}\text { Min = EUR 1,500 } \\
\text { per hotel per year } \\
\text { Max = EUR 6,000 } \\
\text { per hotel per year } \\
\text { Max hotel chain = } \\
\text { EUR 60,000 per year }\end{array}$ \\
\hline \multicolumn{5}{|l|}{ Norway } \\
\hline Products & $\begin{array}{l}\text { MIE }=E U R 350 \\
S M E=E U R 750 \\
B E=E U R 1,500\end{array}$ & $\begin{array}{l}0.15 \% \text { of } \\
\text { annual sales. } \\
\text { Max = EUR 25,000 }\end{array}$ & $\begin{array}{l}\text { Most products }= \\
0.3 \% \text { of annual sales }\end{array}$ & $\begin{array}{l}\text { Min }=\text { EUR } 1,340 \text { per year } \\
\text { Max }=\text { EUR 40,185 per year }\end{array}$ \\
\hline $\begin{array}{l}\text { Services/ } \\
\text { bulk goods }\end{array}$ & $\begin{array}{l}\text { MIE }=E U R 350 \\
S M E=E U R 750 \\
B E=E U R 1,500\end{array}$ & $\begin{array}{l}0.15 \% \text { of } \\
\text { annual sales. } \\
\text { Max = EUR 25,000 }\end{array}$ & $\begin{array}{l}\text { Most services }= \\
0.15 \% \text { of annual sales }\end{array}$ & $\begin{array}{l}\text { Min = EUR 1,340 } \\
\text { per hotel per year } \\
\text { Max = EUR } 6,030 \\
\text { per hotel per year } \\
\text { Max hotel chain = } \\
\text { EUR } 60,300 \text { per year }\end{array}$ \\
\hline \multicolumn{5}{|l|}{ Sweden } \\
\hline Products & $\begin{array}{l}\text { MIE }=E U R 350 \\
S M E=E U R 750 \\
B E=E U R 1,500\end{array}$ & $\begin{array}{l}0.15 \% \text { of } \\
\text { annual sales. } \\
\text { Max = EUR 25,000 }\end{array}$ & $\begin{array}{l}\text { Most products }= \\
0.3 \% \text { of annual sales }\end{array}$ & $\begin{array}{l}\text { Min }=\text { EUR 1,670 } \\
\text { Max }=\operatorname{EUR} 41,800\end{array}$ \\
\hline $\begin{array}{l}\text { Services/ } \\
\text { bulk goods }\end{array}$ & $\begin{array}{l}\text { MIE }=E U R 350 \\
S M E=E U R 750 \\
B E=E U R 1,500\end{array}$ & $\begin{array}{l}0.15 \% \text { of } \\
\text { annual sales. } \\
\text { Max = EUR 25,000 }\end{array}$ & $\begin{array}{l}\text { Most services }= \\
0.15 \% \text { of annual sales }\end{array}$ & $\begin{array}{l}\text { Min }=\text { EUR } 1,670 \text { per year } \\
\text { Max }=\text { EUR } 7,760 \text { per year }\end{array}$ \\
\hline \multicolumn{5}{|l|}{ Finland } \\
\hline Products & $\begin{array}{l}\text { MIE }=E U R 350 \\
S M E=E U R 750 \\
B E=E U R 1,500\end{array}$ & $\begin{array}{l}0.15 \% \text { of } \\
\text { annual sales. } \\
\text { Max = EUR } 25,000\end{array}$ & $\begin{array}{l}\text { Most products }= \\
0.3 \% \text { of annual sales }\end{array}$ & $\begin{array}{l}\text { Min }=\text { EUR } 1,500 \\
\text { Max }=\text { EUR } 34,000\end{array}$ \\
\hline $\begin{array}{l}\text { Services/ } \\
\text { bulk goods }\end{array}$ & $\begin{array}{l}\text { MIE }=E U R 350 \\
S M E=E U R 750 \\
B E=E U R 1,500\end{array}$ & $\begin{array}{l}0.15 \% \text { of } \\
\text { annual sales. } \\
\text { Max = EUR 25,000 }\end{array}$ & $\begin{array}{l}\text { Most services = } \\
0.3 \% \text { of the turnover } \\
\text { of service per year }\end{array}$ & $\begin{array}{l}\text { Min = EUR } 800 \\
\text { Max = EUR 6,000 } \\
\text { per hotel per year } \\
\text { Max hotel chain = } \\
\text { EUR } 45,000\end{array}$ \\
\hline
\end{tabular}

Source: Based on the websites of the ecolabelling secretariats of the Nordic countries and the EU, EU-Ecolabel website. 
In the examples below, it is indicated how the fee structures differentiate as the total annual fees vary according to turnover for three Danish enterprises, varying in size. The examples show the maximum fees for an ecolabelled cleaning product.

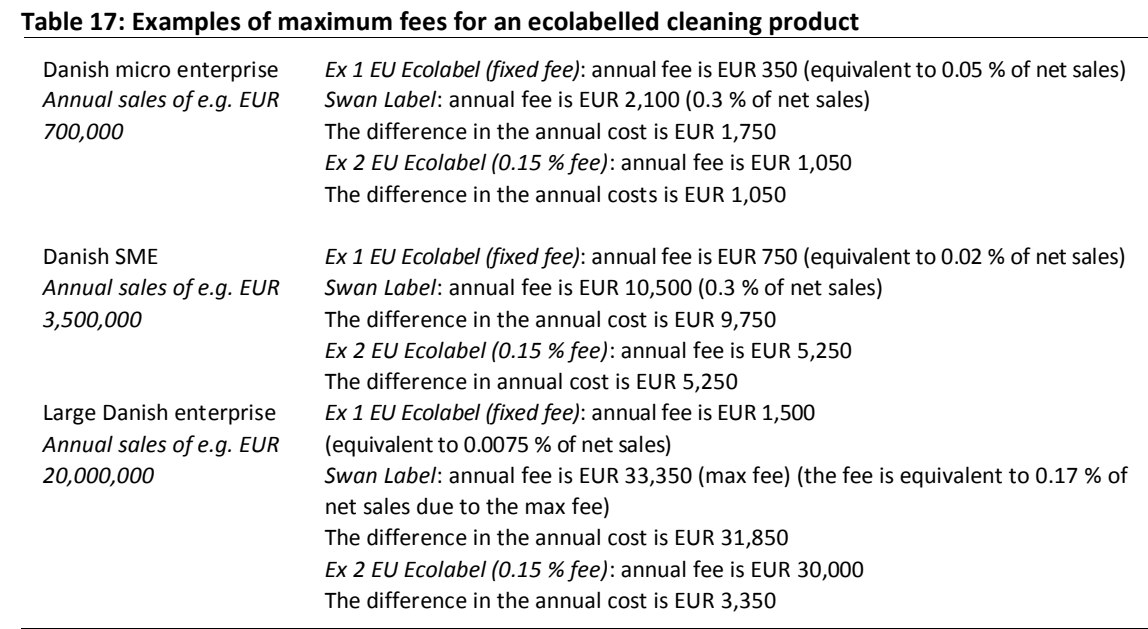

Source: Calculations based on the websites of the ecolabelling secretariats of the Nordic countries.

The examples clearly indicate that the larger the turnover the less the EU Ecolabelled enterprises have to pay in annual fees since the fixed annual fees for the EU Ecolabel represent a smaller amount of the total turnover, compared to the Swan Label. The difference is, however, less significant when applying the EU Ecolabel percentage fee as shown in the examples above.

However, because of the maximum fee for the Swan Label licence holders the percentage of the net sales that large enterprises have to pay is also smaller the higher the turnover.

\subsection{Administrating the ecolabels and prioritisation}

The previous chapter showed how the Swan Label is significantly more acquired by the companies than the EU Ecolabel is. This could lead to consideration as to whether the Swan Label is prioritised in the work of the secretariats.

When interviewing the ecolabelling secretariats of the Nordic countries it is explained how the Swan Label - through the (current) higher fees - brings in a higher revenue than that of the EU Ecolabel. The secretariats explain how they use these means for funding the marketing of 
the Swan Label in the continuing work of sustaining and increasing the awareness and popularity of the Swan Label.

Several of the interviewed secretariats point out that the lower fees of the EU Ecolabel barely cover the costs of running the administration of the label, which could help to explain why the EU Ecolabel is less known than the Swan Label in the Nordic countries. The secretariats at the same time underline that their job is to market both labels towards consumers and companies but that the result follows from the means the more funding available for marketing the higher the likelihood of sustaining and increasing the awareness and popularity of the ecolabels.

The interviewed secretariats generally do not find that it is a problem that the Swan Label is (currently) more expensive than the EU Ecolabel to acquire for companies. They underline that they consider one of the strong sides of the Swan Label to be that it serves as a marketing tool for the companies and that it gives the companies an advantage towards their competitor. It is considered "fair" that companies must pay a fee for this advantage.

\subsection{The direct costs of the ecolabels are important for some companies - less so for others}

As the above has shown there are significant differences in the fees and fee structure of the two ecolabels. But what does this mean for the companies - do they pay attention to the fees of the ecolabels?

It is the impression of some of the interviewed ecolabelling secretariats of the Nordic countries that the fee structure is not important for the companies and that ecolabels are acquired without much attention to the cost.

This observation has some truth to it as interviews performed with Swan labelled companies in relation to another project mostly indicate that the Label is selected based on needs and demand and that the direct costs are less important.28

Furthermore, the surveyed companies having one of the two ecolabels and considering the other have been asked whether they compared the fees of the two ecolabels. As it can be seen, more than half of

\footnotetext{
${ }^{28}$ see "The Nordic Swan and companies - is it worthwhile to acquire the Swan label?", DAMVAD 2013 for the Nordic Council of Ministers, forthcoming).
} 
the companies did not compare the fees of the two ecolabels while $16 \%$ are not aware of whether the comparison was made, and 31\% did compare fees.

Figure 4: Companies comparing the fees of the two labels before the acquisition of one of them

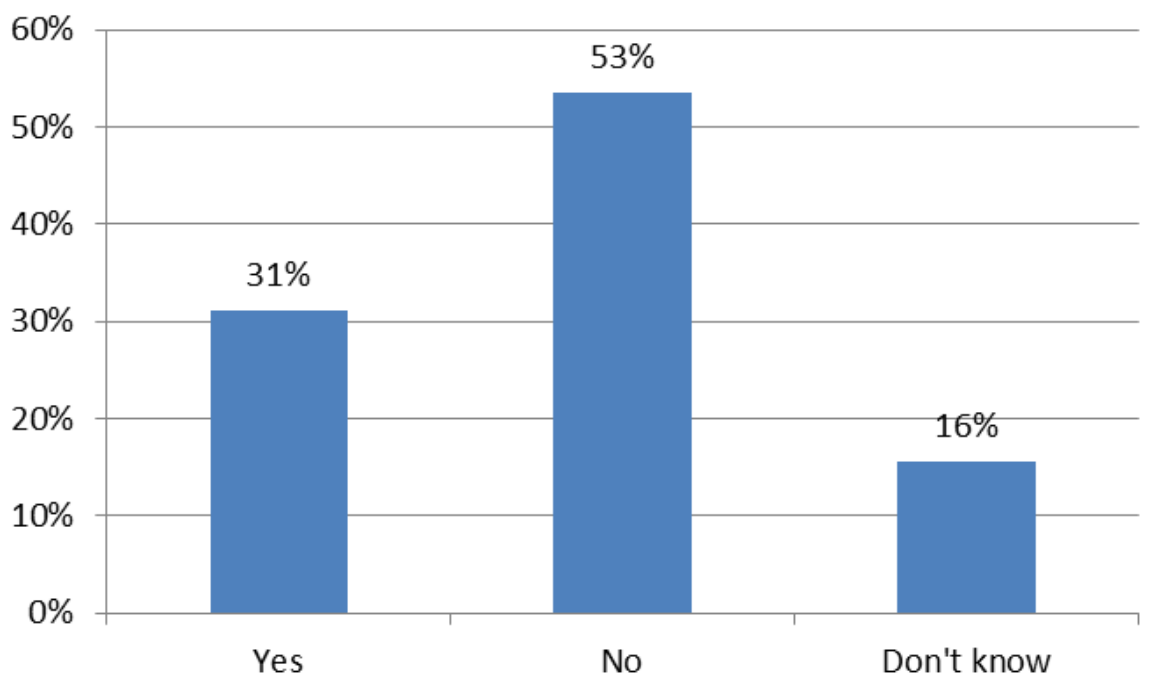

Source: DAMVAD, 2013, based on a survey conducted for the analysis.

Note: $\mathrm{n}=58$.

However, when asking the companies whether they have further comments on the Swan Label or EU Ecolabel at the end of the survey a number of the companies carrying the Swan Label indicate (without being influenced to do so) that they believe it should be less expensive to acquire the Swan Label. A few companies even indicate that they are considering leaving the label as they find it too expensive.

Still, many companies choose to acquire the Swan Label - also even after they have been informed of the differences in costs. The companies are driven by other factors, such as the wish to obtain or sustain a green profile, the hope for higher sales, a wish to implement green improvements in the production/company as a whole, market demand, etc. - see chapter 4 above for details. In addition, in many cases the Swan Label has a strong brand and is well known among consumers making it the obvious choice.

Thus, for some companies the direct costs of acquiring an ecolabel are important, while for others other factors are overshadowing the direct costs. 


\subsection{Possibilites to lower the fees and administrative burdens when applying for both ecolabels}

A large number of the companies find, not surprisingly, that when applying for both of the ecolabels there should be some advantages - either administrative or economic. Thus, $80 \%$ of the companies find that there should be administrative advantages when applying for both labels while $76 \%$ believe it should be less expensive when acquiring both labels.

\section{Figure 5: Companies view on having both ecolabels}

There should be administrative advantages for companies wanting to have the Nordic Ecolabel (the Swan) if you already have the EU Ecolabel (the Flower) or vice versa and the criteria are alike

It should be less expensive for companies to acquire the Nordic Ecolabel (the Swan) if you already have the EU Ecolabel (the Flower) or vice versa and the criteria are alike

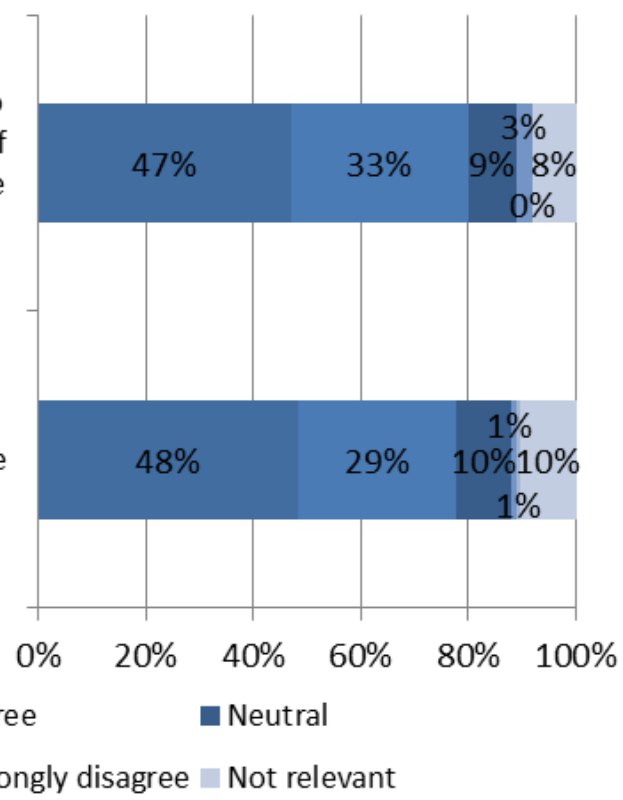

Source: DAMVAD, 2013, based on a survey conducted for the analysis. Note: $\mathrm{n}=174$

As it will be seen in the chapter below the Swan Label has for some product categories harmonised the criteria with the EU Ecolabel. This means that for some product categories (e.g. audiovisual equipment) only a few supplementary criteria must be fulfilled besides the criteria of the EU Ecolabel, in order to obtain the Swan Label. For other product categories (e.g. indoor paints and varnishes) the criteria are completely similar. 
In cases of complete similarity between the criteria applications for both the Swan Label and the EU Ecolabel for a single product, companies are entitled to a discount. ${ }^{29}$

Furthermore, the differences in the fee structure has been discussed with the ecolabelling secretariats in the Nordic countries as explained above. These point out that it is possible to lower the fees for the Swan Label - however, this will have a direct effect on the marketing possibilities. In most of the Nordic countries, the ecolabelling secretariats spent a relatively large amount of the revenues from the application fees and annual fees to promote the Nordic Ecolabel nationally. If fees are lowered, the consequences are either that resources on marketing must be reduced or that the national funding must be increased further to sustain the level of marketing effort currently in place.

Another possible consequence of lowering the fees brought up during interviews with the secretariats is that companies may find that the value of their ecolabel decreases as more companies join. The ecolabels may become more unattractive if ecolabelling is made free of charge. However as no companies have been interviewed, it is not possible to confirm this explanation.

${ }^{29}$ According to the criteria documents. See e.g. the criteria document for indoor paints and varnishes: http://www.ecolabel.dk/kriteriedokumenter/096e_2_2.pdf 


\section{Comparing the licence criteria}

Comparing the criteria of the Swan Label and the EU Ecolabel is a complex task. The criteria documents are very thorough and detailed and not structured in similar ways. This makes it tricky to compare the criteria of the two ecolabels directly, even if they have overlapping product groups.

The criteria comparison has been done threefold and looked further into the width of the product category, the modes of application of the criteria, e.g. thresholds or score systems, and the specific content it pays attention to, e.g. environmental requirements and packaging requirements.

The comparison is based on available criteria documents online. The appendix shows the documents used. Only product groups which are overlapping between the Swan Label and the EU Ecolabel are compared in the following. Furthermore, product groups where the two labels have completely similar criteria or nearly so, such as audiovisual equipment, textiles and indoor paints and varnishes, have not been compared for obvious reasons.

In comparing the two ecolabels criteria document and analysing the differences in "strictness," it is also important to take into consideration differences in time of adoption, which can partly explain the differences (in both labels favour).

\subsection{Heat pumps - differences within the width of the criteria}

The Swan Label's category for heat pumps is wider than that of the EU Ecolabel's. Apart from the single heat pump the Swan Label criteria also covers entire heat pump systems.

That being said, the set of criteria seem quite similar in terms of mode and content. Both labels require fulfillment of each requirement. Regarding the content of requirements both labels largely emphasise the same parameters. For refrigerants they emphasise GWP, 30 for secondary refrigerants both labels apply EU directive 67/548/EEC, for flame re-

30 Global warming potential. 
tardants they refer to directive 2002/95/EC, for testing both labels require EN ISO/IEC 17025 (noise and efficiency) and EN 14511 and both require a specification the product's noise level.

The content differences between the criteria seem limited. However, a few points can be highlighted. The Swan Label depicts requirements regarding phthalates and organic solvents, whereas the EU Ecolabel's requirements in terms of heat efficiency seem more detailed than the Swan Label's.

In total it seems that for heat pumps the criteria of the ecolabels are quite similar with the largest difference being within the width of the criteria.

\subsection{Laundry detergents and stain removers - differences within the criteria mode and content}

The two ecolabels are similar in terms of the width of the product category primarily containing laundry detergents for household use. Generally, the largest differences can be found within the mode of the criteria. All requirements must be met under the Swan Label, while the EU Ecolabel can be obtained by scoring a certain amount of points within a range of categories. ${ }^{31}$ This means a product not necessarily needs to meet all criteria to obtain the EU Ecolabel. ${ }^{32}$ Further, enforcement of the Swan Label includes on-site inspections.

In terms of content of the criteria for laundry detergent the picture is not entirely clear; in a number of sub-criteria they are alike, but this is modified in some areas where the Swan Label spells out more requirements. Inspection of ingredients both refer to EU regulations ${ }^{33}$ of hazardous effects and fragrance levels as well as the International Fragrance Association's requirements. For dosage and ecotoxicity the criteria comparison is difficult because of the different measurement units which the two labels apply, ${ }^{34}$ For both labels the criteria are maximum thresholds, e.g. for critical dilution volume (CDV) and biodegradability of organics. The labels differ somewhat in respect of excluded substances. The Swan Label exclusion list holds more substances than the EU Eco-

\footnotetext{
31 E.g. climate, maximum dosage, $\mathrm{CDV}$, aNBO/anNBO.

32 Criterion 7, 2011/264/EU.

33 1272/2008 and 67/548/EEC, fragrance 648/2004/EEC

34 The Swan Label uses soft water while the EU Ecolabel uses 2,5 mmol CaCO3/l.
} 
label. On the other hand the Swan Label recognises levels of phosphorous, which is an excluded substance of the EU Ecolabel criteria. Further the Swan Label has requirements to traceability of ingredients, e.g. raw materials, which the EU Ecolabel does not address.

Summing up, the mode of enforcement, point systems versus mandatory requirements, seems to be the largest difference between the two labels. The content of the criteria is quite similar with some deviations that do not seem to be so systematic that one can be said to be stricter than the other. The ambition to harmonise the criteria is within reach since the Swan criteria document states that the future for this product category is a harmonisation of the criteria with the EU Ecolabel's (Nordic Ecolabelling 2012:21).

\subsection{Floor coverings - differences within the width of the criteria}

In terms of width, the two ecolabels cover different types of floor coverings. The EU Ecolabel certifies hard natural materials, e.g. natural stone or ceramic tiles, which can be used indoor and outdoor. These differences obviously affect content and mode of the criteria and make a precise comparison redundant. The EU Ecolabel's criteria documents for floor coverings are three separate documents divided into "hard coverings", "wooden floors" and "textile floor coverings". The Swan Label's criteria are gathered in one document covering indoor use of e.g. the materials bamboo, wood and parquet. Both labels cover different kinds of wooden floors.

The mode of criteria varies according to the materials used. For hard floor coverings the EU Ecolabel combines a score system with regards to extraction of the materials with a range of limits on different parameters relying on relevant EU legislation. Like in all other categories the Swan Label has on-site inspections. Key to the Swan Label's criteria is that of $50 \%$ of the materials' weight must comprise of renewable materials.

The content of the criteria vary considerably according to the different materials. Both labels pay attention to the effects of extraction, e.g. on the environment they are extracted from, energy consumption and waste management in the production process. But the precise contents vary according to the differences in materials. The extraction of stones is e.g. connected with quite some risks. The Swan Label has criteria concerning the final product and the amount of health- and environmental damaging substances. The EU Ecolabel is concerned with the finishing operation of the raw materials. 


\subsection{Tissue paper - noteworthy differences in content}

The width of the criteria for the ecolabels with regards to tissue paper is largely similar. They both comprise tissue paper covering personal hygiene and cleaning of soiled surfaces.

The ecolabels are similar in combining point systems for environmental effects of the production, e.g. concerning emissions to water and air and setting up thresholds for chemicals and hazardous substances. The Swan Label's criteria are compounded of three modules; basic and chemical modules concerning all paper products labelled by the Swan Label and a supplementary module that only contains tissue paper while the EU Ecolabel's criteria is gathered in one piece.

The content of the criteria are similar in some areas but differ in others. Generally, the labels are quite similar in terms of energy, where they target the production (and not transport), emissions to water and air $\mathrm{CO}_{2}$ and traceablity of fibres, e.g. origin from legal sources. Different measurement units make a direct comparison difficult. Worth mentioning is the Swan Label's criteria that exclude all kinds of fragrance while the EU Ecolabel is not as absolute. Further the Swan Label has separate criteria for packaging, absorption standards and some stricter values for harmful products, e.g. pentachlorophenols, PCP. 35

Overall, the labels have largely similar criteria in environmental requirements, though direct comparison is difficult caused by the measurement units used. However, some interesting differences occur in product safety and quality, where the Swan Label has stricter criteria with regards to some chemicals, e.g. fragrance exclusion, and product function.

\subsection{Cleaning products - differences in width and mode}

Although the product groups largely cover similar products different subgroupings of the category ${ }^{36}$ leads to differences in the width of the criteria. The Swan Label excludes certifying certain "special cleaning products," e.g. scouring creams, which the EU Ecolabel covers. The EU

\footnotetext{
35 Verion 5.0 Nordic Ecolabelling of Tissue Paper 5.0.

${ }^{36}$ EU Ecolabel covers all-purpose, window and sanitary cleaners (both bathroom and kitchen). The Swan Label also has sanitarycleaners but the rest divided into fixed surfaces and kitchen equipment. The aspect of dilution is taken into account whan applying criteria.
} 
Ecolabel's category is wider in terms of including product types whereas the Swan Label appears stricter in excluding some of these types.

Considerable differences can be found in the mode of the criteria and the way they are applied. The Swan Label's criteria relate to all deliberately (and not counting pollution) ingoing substances (exept where described otherwise). The EU Ecolabel's criteria apply to substances weighing over $0.01 \%$ of the final weight (and also include pollution). ${ }^{37}$ This difference in measurement thresholds indirectly impacts the totality of the contents criteria reviewed in the following.

Apart from the different way of applying the criteria the labels are similar in formulating thresholds within largely the same parametres. Both labels address low impact on the environment and on the chemicals used in the products. Further, they are similar in excluding chemicals, hazardous effects, fragrance restrictions, critical dilution volumes and biodegradeability. Direct comparison is made difficult by the EU Ecolabel's grouping of criteria for the subgroups. However the Swan Label's criteria are stricter regarding e.g. phosphorous.

In conclusion, there is a difference in the width of the product groups with the Swan Label's narrower definition. The EU Ecolabel certifies e.g. scouring cream which the Swan Label's criteria exclude in this category. Apart from this, the largest difference is in the mode; where the Swan Label has requirements broader in claiming all in-going substances the EU Ecolabels criteria need to be met for only certain ones.

\subsection{Hand dishwashing detergents - noteworthy differences in content}

The width of the two ecolabels' criteria is similar within the hand dishwashing detergents category. Both cover products for household use and professional use.

Similar to the cleaning products group above, the labels differ in the mode of applying the criteria. The Swan Label's criteria apply to all deliberately (and not counting pollution) added substances whereas the measurement threshold for the EU Ecolabel is when ingredients weigh more than $0.01 \%$ of the product's final weight (including pollution). In

37 Commission Decision of 28 June 2011, p. 3 
general, this distinction implies that the EU Ecolabel's criteria apply to fewer parts of the products compared to the mode for the Swan Label.

Substantial differences within the content of the criteria can be highlighted. The differences occur within dosage, biodegradabilty and packaging. For example the Swan Label has a maximum limit to dosage and has less permitting thresholds than the EU Ecolabel for anaerobic biodegradabilty, critical dilution volume (CDV). For the packaging criteria the Swan Label excludes e.g. polyvinyl chloride, PVC, and demands taking national take-back systems into account while, furthermore, having extensive requirements to the performance of the product. That being said the labels have largely similar criteria in prohibited/limited substances, where they refer to EU regulation ${ }^{38}$ and fragrances (in accordance with IFRA and excluded in products for professional use).

The differences both in mode of the criteria and in the aspects of the dosage and biodegradeability are noteworthy. The Swan Label's thresholds are less permitting and more comprehensive.

\subsection{Dishwasher detergents - differences on all dimensions}

The ecolabels are largely similar but differ in the way that "rinsing agents" can be certified when comparing criteria for dishwashing detergents. The EU Ecolabel's category enables certification of rinsing agents. The Swan Label enables "rinsing agents" to be certified only in combination with a primary detergent.

Also when it comes to the mode of the criteria, there are differences between the two labels. The Swan Label combines obligatory requirements with a point system where a minimum has to be achieved. The EU Ecolabel does not distinguish and all criteria have to be met. As for the cleaning products and hand dishwasher detergents the EU Ecolabel has measurement thresholds dependent on the nature of the substances. Preservatives etc. have to meet criteria regardless of the amount while constituent substances do not meet criteria after the defined threshold of $0.01 \%$ of the product's final weight.

The Swan Label and the EU Ecolabel have similar requirements on particular substances, hazardous substances and biodegradeability, fra-

38 Directive 67/548/EEC and No 1272/2008. 
grance, and performance requirements, encouraging lowest possible temperatures. Like for handwasher detergent the Swan Label's criteria comprise thresholds for maximum dosage with the point system rewarding low dosages and stringent criteria for packaging regarding the use of PVC. The EU Ecolabel has another variant of maximum dosage, similar to the Swan Label's, but measured in "total chemicals." Comparison is difficult but the Swan Label's maximum is less than that of the EU Ecolabel. Although largely similar the labels differ in limits for CDV and phosphorous requirements where the Swan Label's limits are less strict than those of the EU Ecolabel. This can be ascribed to the point score system of the Swan Label. However, the Swan Label foresees the undergoing of a strengthening of the criteria for phosphates in the future revisions of their criteria (Nordic Ecolabelling of Dishwasher detergent 5.2: p. 18).

Also in this category the result of the comparison is complex. The two labels vary both within width, mode and content. In total, the largest differences lie within the mode of the criteria. The Swan Label's combination of mandatory criteria and point score allows some criteria to be less strict. This does not mean that the criteria are less strict, however, as other areas might be caught by the point system. Moreover, this is also counterbalanced by the fact that all substances are required to meet the criteria, where this is only the case for substances weighing over $0.01 \%$ of the final weight of the EU Ecolabelled products. Furthermore, the content of the criteria for packaging are more comprehensive under the Swan Label than for the EU Ecolabel.

\subsection{Copy and printing/graphic paper - high level of similarity but slight differences in content}

The EU Ecolabel and the Swan Label's specific titles for this category differ, but the criteria documents largely cover the same product types. The compliance structures are similar in the way that on-site inspections are possible for both labels. Furthermore, the mode of the criteria is similar in demanding that all requirements are met. The Swan Label has separate modules for paper products - a basic and a chemical module supplementing the copy paper criteria. This makes the Swan Label's criteria appear quite comprehensive.

Despite the comprehensive modules for paper products under the Swan Label the labels are largely similar in terms of content. However, they do have different approaches. Ecological criteria cover production of pulp and all sub-processes. Both have criteria within energy use, 
emission to water and air, composition of fibre raw materials and use of chemicals in production. The labels have slightly different approaches to traceability of wood and fibre through the chain of custody. As an example the EU Ecolabel demands all virgin fibres to be certified, but sets up a maximum for uncertified material (but still controlled by the wood certifier) of 50\%. The Swan Label requirements apply to annual production requiring a minimum of $30 \%$ of fibres to come from certified sources or $75 \%$ from recycled (Nordic Ecolabelling of paper products - Basic Module 2.0, p. 10). Furthermore, the Swan Label requires documentation for the impact on $\mathrm{CO}_{2}$ of all forms of transport - a criterion which is not mirrored by the EU Ecolabel (Nordic Ecolabelling of Paper products - Basic Module 2.0, p. 11). As in other product categories described above the Swan Label targets the national take-back systems.

In total there are slight differences in the content but generally the criteria of the two labels are quite similar.

\subsection{Systematic differences across product types}

The criteria comparison has reviewed the criteria of eight product categories in respect of three parameters; width, mode and content of the criteria. The cases cover a large variety of products: two paper products, four cleaning products and two other manufactured goods. Interestingly, across the three types of products the criteria seem to differ on the same dimensions which the table below shows. For the paper products tissue paper and copy paper the differences occur within the content of the criteria. For the manufactured goods the criteria vary in the width. For the four remaining product categories covering different kinds of cleaning products the criteria differ in more than one dimension, however, each being different in mode. Thus, the criteria structure of the labels tends to differ on the same dimensions.

The comparison has highlighted that the general differences in the width dimension concern "how broad" to certify. The differences in the mode dimension concern the fundamental structure. Here, an interesting observation in the Swan Label's criteria is that inspections are required while this is voluntary for the EU Ecolabel, although ususally these are performed in the Nordic countries. Furthermore, the Swan Label criteria require to take take-back systems into account. The differences in terms of the content dimension consist of quite some technicalities. The labels often address the same themes, however, they do this with varying strength. Both to a large extent refer to EU regulation. Generally, it can 
be pointed out that the Swan Label's criteria often seem more comprehensive and with a very high level of detail. Another general difference is within fragrance, exclusion and threshold levels of certain substances. Finally, a direct comparison of content is made difficult due to the different measuring units applied by the labels.

\begin{tabular}{llccc} 
Table 18: Criteria differences: Comparison of criteria across eight product categories & \\
\hline Product type & Product category & Width & Mode & Content \\
\hline Manufactured goods & Heat pump & $\mathrm{X}$ & & \\
& Floor coverings & $\mathrm{X}$ & & \\
& & & $\mathrm{X}$ & $\mathrm{X}$ \\
Cleaning products & Laundry detergents & $\mathrm{X}$ & $\mathrm{X}$ & $\mathrm{X}$ \\
& Cleaning products & & $\mathrm{X}$ & $\mathrm{X}$ \\
& Handdishwashing detergent & $\mathrm{X}$ & $\mathrm{X}$ & $\mathrm{X}$ \\
& Dishwasher detergent & & & $\mathrm{X}$ \\
\hline
\end{tabular}

Source: DAMVAD, 2013, based on the websites of the Nordic ecolabelling secretariats. 



\section{International experience on co-existence between ecolabels}

The following chapter takes a case-based approach and presents the experience of other European countries operating with two ecolabels. The countries examined are Germany, the Netherlands, Austria and France.

\subsection{Ecolabels in Germany}

\subsubsection{The German case}

There are two ecolabels represented on the German market today these are the EU Ecolabel and the Blue Angel.

The Blue Angel is the first and oldest environment-related label for products and services in the world. It was created in 1978 on the initiative of the German Federal Minister of the Interior and approved by the Ministers of the Environ-ment of the federal government and the federal states. Today, about 11,700 products and services in around 125 product categories carry the Blue Angel ecolabel. The ecolabel is administered by the Ministry of Environment, and the Environmental secretariat carries out the day-to-day work.

The EU Ecolabel was introduced on the German market in the mid 90s.

\subsubsection{Co-existence between the ecolabels}

RAL $\mathrm{gGmbH}$ is responsible for administrating applications and licences for the Blue Angel and the EU Ecolabel. RAL and GEPA are both also represented in the EU Ecolabel board (EUEB). According to the representative in the German Environmental Agency the two ecolabels co-exist well - however, they are not as closely linked as the ecolabels are in the Nordic countries. The coordination between the two ecolabels is described in the EU Ecolabel regulations. 
The two labels have only a few product groups in common - these are for instance: textile, footwear, computers and tele and different coverings. The criteria or fees for the two ecolabels have not been aligned and according to the German Environmental Agency the criteria are different and difficult to streamline.

\subsubsection{Difference in awareness and dissemination}

According to the Agency the Blue Angel is very well recognised among the German consumers as around $90 \%$ recognise the ecolabel. The Blue Angel licence holders have to pay a certain percentage of their sales which is then spent on marketing the ecolabel. A greater amount of resources is hence spent on the marketing of the Blue Angel compared to the EU Ecolabel.

In comparison, the EU Ecolabel is only recognised by less than $10 \%$ of the consumers in Germany. Companies based in Germany therefore prefer the national ecolabel whereas companies that want to address bigger markets more often choose the EU Ecolabel. Only very few companies have applied for both ecolabels and there are no economic advantages for the companies that have chosen both.

\subsection{Ecolabels in the Netherlands}

\subsubsection{The Dutch case}

Milieukeur is the Dutch environmental quality label for products and services that was introduced in 1992-1995. There are Milieukeur criteria for a wide variety of food products, consumer products and services, ranging from vegetables, potatoes, fruit, beer, pork, trees and plants to concrete products, fire extinguishers, florists, butchers, green electricity and car washes. Milieukeur is supported by the Dutch government.

\subsubsection{Co-existence between the ecolabels}

According to the Dutch Environmental Agency the criteria for the mutual product groups within Milieukeur and the EU Ecolabel have been aligned in the previous years due to the evolution of the EU product criteria. Instead of handling two different sets of criteria for the same product groups the Milieukeur criteria have been phased out and re- 
placed by the EU criteria. The ecolabels therefore co-exist very well and there is no competition between the labels.

The alignment of criteria has been welcomed by both companies and consumers because it is more transparent and simple to compare different products now. As the EU Ecolabel does not cover any food products Milieukeur is still the leading national ecolabel within these product groups.

\subsubsection{Difference in consumer and business awareness}

The Dutch Environmental Agency and SMK administers both ecolabels but the agency allocates more resources in handling EU Ecolabel requests.

According to the agency representative the business awareness of both ecolabels is quite well. The main interest comes from hotels that use e.g. ecolabelled laundry detergents and cleaning products in their hotels. Awareness around consumers is lower and neither of the ecolabels are very well known in the Netherlands. Contrary to Germany and the Nordic countries the consumers still have a better knowledge of the EU Ecolabel than the national ecolabel.

\subsection{Ecolabels in Austria}

\subsubsection{The Austrian case}

There are two ecolabels represented on the Austrian market - the EU Ecolabel and the national Austrian ecolabel - Das Österreichische Umweltzeichen.

The Austrian Ecolabel was introduced to the Austrian market in 1990 - three years before the EU Ecolabel. The Austrian Ecolabel exists within a number of product categories, some of which are overlapping with the EU Ecolabel.

\subsubsection{Co-existence between the ecolabels}

The Austrian consumer association is administering both of the ecolabels in Austria and take care of development of criteria, certification processes, etc. The consumer association has a contract with the Austrian Ministry of Environment who is the responsible authority. According to the interviewed representative of the consumer association the two labels co-exist without major challenges and are expected to continue to do so in the future. 
The product groups for which the national ecolabel is targeted are selected and developed according to the needs on the market. Also, the national ecolabel has had categories developed when it was found that the criteria of the EU Ecolabel were not strong enough. This is the case for paint. Consideration is also paid towards whether there are other strong labels or standards within the product group already. It has e.g. been considered to introduce a product group for textiles under the Austrian Ecolabel but this has until now not been introduced as there are other strong labels existing (such as the EU Ecolabel).

For some product groups the EU Ecolabel criteria have been adopted into the national ecolabel criteria. This goes for e.g. handwashing soaps. When such an overlap occurs it is possible for applying companies to acquire both labels within one licensing process. Furthermore, in cases of $100 \%$ overlap the companies only pay the price of the EU Ecolabel licence. Within product groups where the criterias are nearly similar the companies can still acquire both labels within one licensing process and pay the fee for the EU Ecolabel plus 50\% of the fee for the Austrian Ecolabel.

\subsubsection{Difference in awareness and dissemination}

Much like Germany and the Nordic countries the national ecolabel is more known among consumers than the EU Ecolabel is - the national label is recognised by $50 \%$ of the consumers whereas the EU Ecolabel is recognised by around $25 \%$. As a consequence of this most companies wish to have the national label on their products, particularly if they are selling to the Austrian market. However, there are also areas where both labels are popular - e.g. within tourism where companies will often carry both labels.

\subsection{Ecolabels in France}

\subsubsection{The French case}

As for the other countries there are two ecolabels represented on the French market - the EU Ecolabel and the national French ecolabel - la marque NF Environnement.

The French Ecolabel was introduced to the French market in 1991. La marque NF Environnement exists within a number of product categories, however, not within the same product categories as the EU Ecolabel. 


\subsubsection{Co-existence between the ecolabels}

As for the other countries both of the ecolabels are administered by the same organisation, the AFNOR Certification which handles certification, licensing, etc.

Regarding co-existence a significant difference exists between France and the other countries examined. With the exception of 1-2 categories the national French Ecolabel is targeted towards categories which are not part of the Eu Ecolabel. Thus, the AFNOR Certification has chosen a strategy which is different from the other countries.

The AFNOR Certification finds that it is an advantage to have this strategy since it takes away some of the confusion among consumers and companies of having two competing labels.

\subsubsection{Difference in awareness and dissemination}

The awareness of the labels differ depending on the product categories. The EU Ecolabel is well-known among consumers within tourist accommodation in France while the national ecolabel is strong and well-known on other areas. 



\section{Reference list}

DAMVAD 2013, "The Nordic Swan and companies - Is it worthwhile to acquire the Swan label?", for the Nordic Council of Ministers, forthcoming. (DOI: http://dx.doi.org/10.6027/TN2014-523).

YouGov, Jan 2013, “Miljømerking - Nordisk forbrukerundersøkelse 2013."

\section{Websites:}

http://www.nordic-ecolabel.org/about/

http://www.ecolabel.dk/da/blomsten-og-svanen/

http://www.nordic-ecolabel.org/criteria/product-groups/

http://stats.oecd.org/

http://www.nordic-ecolabel.org/criteria/the-criteria-process/

http://ec.europa.eu/environment/ecolabel/

http://www.ecolabel.dk/da/produkter/ /

link.aspx?_id=D1BE384444A54415B0417CF318B4E9B7\&_z=z

http://ec.europa.eu/environment/ecolabel/information-and-contacts.html http://ec.europa.eu/environment/ecolabel/how-to-apply-for-eu-ecolabel.html http://www.ecolabel.dk/da/in-english/what-does-an-ecolabel-cost/eu-ecolabel/ http://www.ecolabel.dk/kriteriedokumenter/096e_2_2.pdf

http://www.ecolabel.dk/NR/rdonlyres/

360D3BF9-3061-432A-B096-9EEED513BD24/0/FeesBlomsten.pdf 



\section{Sammenfatning}

Nordisk Ministerråd har bedt DAMVAD om at udarbejde en analyse af forholdet og sameksistensen mellem det nordiske miljømærke - Svanemærket og EU Ecolabel - Blomsten, i de nordiske lande. Formålet med analysen er at se nærmere på synergier og forskelle mellem de to mærker. Følgende tre temaer undersøges:

- Svanemærkets og EU Ecolabels positionering og succes inden for forskellige produktkategorier.

- Synergier og positionering mellem afgifts- og kriteriestrukturer for Svanemærket og EU Ecolabel.

- Erfaringerne med sameksistens mellem EU Ecolabel og andre nationale og regionale miljømærker.

For at kunne udarbejde analysen er en række metodologiske elementer blevet anvendt - herunder desk research, interviews og analyse af tilgængelige information fra hjemmesiderne for de nationale miljømærkningskontorer i de nordiske lande. Endelig er der blandt licenshaverne af Svanemærket, EU Ecolabel eller begge mærker foretaget en spørgeskemaundersøgelse i de nordiske lande.

\subsection{Konklusioner og anbefalinger}

\subsubsection{Svanemærket dominerer inden for serviceerhvervene}

Analysen har vist, at Svanemærket har en dominerende position i de nordiske lande, og at det anvendes i væsentlig højere grad end EU Ecolabel. De to mærker afviger endvidere betydeligt i deres position på tværs af brancher. Analysen viser, at Svanemærket står særligt stærk inden for tjenesteydelser såsom hoteller, trykkerier m.fl. og inden for produkter såsom rengøringsmidler, kosmetik m.fl. Den stærke position inden for services skyldes bl.a. at større kæder vælger at svanemærke alle deres butikker, som alle tæller med i opgørelsen. EU Ecolabel står stærkt inden for campingpladser og blandt produkter inden for kategorier såsom tekstiler, maling, papirvarer osv. Når man sammenligner positioner på 
tværs af lande, er Sverige frontløber for Svanemærkede produkter og tjenesteydelser efterfulgt af Danmark, Norge og Finland, mens Danmark er frontløber for EU Ecolabel.

\subsubsection{Svanemærket er dyrere, men brugerne er generelt ikke prisfølsomme}

Desuden har analysen vist, at afgifterne for Svanemærket generelt er højere end for EU Ecolabel. Der er dog undtagelser til dette. Ansøgningsgebyret er højere for Svanemærket, med undtagelse af ansøgningsgebyret for store virksomheder, hvor ansøgningsgebyrerne bliver ens, såfremt en ny prisstruktur for EU Ecolabel implementeres. For fornyelsesgebyrer er Svanemærket dyrere for mikrovirksomheder, men billigere for store virksomheder (under EU Ecolabels nye struktur). For de årlige gebyrer er EU Ecolabel mindre omkostningsfuld for virksomheder der mærker produkter, uanset om den nye eller gamle prisstruktur anvendes. For services er EU Ecolabel mindre omkostningsfuld under den nuværende prisstruktur, og har samme pris som Svanemærket under den nye struktur. Det bemærkes dog, at EU Ecolabel vil have en maksimumgrænse under det nye system, der vil være billigere end Svanemærkets for produkter, men højere for services.

Endvidere er afgiftsstrukturen for EU Ecolabel enklere end for Svanemærket. Beregnede eksempler, på de afgifter en virksomhed skal betale viser, meget store forskelle med EU Ecolabel som langt den billigste. Analysen viser dog også, at mens nogle virksomheder betragter de direkte omkostninger af mærket er mere end $50 \%$. af virksomhederne, der enten har Svanemærket eller EU Ecolabel, ikke opmærksom på disse omkostninger, men er i stedet drevet af forbrugernes efterspørgsel, ønsket om at opnå/vedligeholde en grøn profil m.v. Yderligere er Svanemærket i mange tilfælde et stærkt brand og er velkendt blandt forbrugerne, hvilket gør det til det oplagte valg.

\subsubsection{Svanemærkets kriterier lægger vægt på detaljer og kontrolbesøg}

At sammenligne kriterierne for de to miljømærker er en kompliceret opgave. Kriterierne er ikke struktureret på samme måde og dækker ikke altid dækker de samme egenskaber - selv når kategorierne er overlappende. Der forekommer imidlertid systematiske forskelle på tværs af produktkategorier, når man ser på kriteriernes omfang ("bredden" hvad der er omfattet af kriterierne), anvendelse (hvordan kriterierne 
benyttes, fx gennem pointsystemer) og indhold (hvad kriterierne fokuserer på, fx miljøkrav, emballage osv.). I forhold til kriteriernes omfang kan forskelle ses i, hvor "bredt" miljømærkerne certificerer - i nogle tilfælde har Svanemærket en "bredere" dækning, i andre er det EU Ecolabel. I forhold til anvendelsen har Svanemærket som krav at der gennemføres kontrolbesøg - hvilket EU Ecolabel har som et frivilligt element, men som oftest genemføres disse i Norden. I forhold til indholdet berører miljømærkerne ofte de samme temaer, men med varierende styrke. Svanemærket kriterier forekommer i de fleste tilfælde at være mere omfattende og med en høj detaljeringsgrad.

\subsubsection{Den internationalt udsyn: differentiering og assimilation}

Endelig ser analysen på strategierne for andre lande, der har to miljømærker. Den tyske situation er meget lig den nordiske med et meget stærkt nationalt miljømærke ud over EU Ecolabel. Som sådan har Tyskland valgt en differentieringsstrategi og deved at opretholde et stærkt nationalt mærke. I Nederlandene er en assimilationsstrategi blevet valgt: når kriterier udvikles inden for en produktkategori, som både er dækket af et nationalt mærke og af EU Ecolabel, er de nationale kriterier blevet udfaset og erstattet af kriterierne for EU Ecolabel. I Østrig er både en assimilations- og differentieringsstrategi blevet valgt. For nogle kategorier er kriterierne for EU Ecolabel blevet adopteret, så de også gælder for det nationale miljømærke. For andre produktkategorier har man imidlertid besluttet, at kriterierne for EU Ecolabel ikke var stærke nok, og strengere kriterier for det nationale miljømærke er i stedet blevet udviklet. Endelig har Frankrig valgt en helt anden strategi for deres nationale miljømærke og fastlægger kun kriterier inden for kategorier, der ikke er omfattet af EU Ecolabel.

På baggrund af analysen og ovenstående konklusioner anbefales følgende for det fremtidige arbejde med Svanemærket

- Konsolider og byg videre på den stærke position i serviceerhvervene En stærk komparativ position inden for serviceerhvervene er en klar fordel og en differentieringsakse for Svanemærket. Desuden er tjenesteydelser af voksende betydning for moderne økonomier som de nordiske, og det er ofte vist, hvordan tjenesteydelser udgør op til 
$70-80 \%$ af et lands BNP og fortsætter med at vokse. ${ }^{39}$ Svanemærkets komparative position inden for tjenesteyderlser såsom hoteller og trykkerier er derfor vigtig og bør konsolideres yderligere. Desuden viser en anden undersøgelse af Svanemærket (Se "The Nordic Swan and companies - Is it worthwhile to acquire the Swan label?", DAMVAD 2013 for Nordisk Ministerråd, kommende udgivelse, DOI: http://dx.doi.org/10.6027/TN2014-523), at Svanemærkets effekt på virksomhedernes adfærd er større for servicevirksomheder end den er for produktionsvirksomheder. Denne effekt er relateret til virksomhedernes omkostninger, men især til deres miljøeffekter. Dette indikerer, at der er "lavthængende frugter" at plukke for både servicevirksomheder og Svanemærkets fremtid.

Denne stærke position inden for tjenesteydelser forekommer at være mest evident i Sverige og mindre tydelig i andre lande. Tager man dog den større indvirkning på servicevirksomheder og deres succes $\mathrm{i}$ Sverige i betragtning - også med tanke på konkurrencen med andre miljømærker - bør det overvejes at konsolidere og bygge videre på den stærke position i serviceerhvervene på tværs af alle nordiske lande. Det bemærkes dog, at certificeringen af services er mere omkostningstungt for miljømærkesekretariaterne, end det er for fysiske produkter.

- Prioriter udbredelse i højvæksterhverv, der er specifikke for Norden Hvis man følger denne tankegang, kan et fokus på udvikling og udbredelse af Svanen i andre højvækstområder, der er specifikke for nordiske økonomier, vise sig at være en frugtbar vej for Svanemærket - både i forhold til at udbrede mærket og i forhold til at skabe merværdi ved at adskille sig fra EU Ecolabel.

- Bliv et "high-end" mærke i konkurrenceprægede industrier Som beskrevet ovenfor har andre lande, der har et nationalt miljømærke og EU Ecolabel, valgt forskellige strategier for sameksistensen af disse mærker. De lande, der har stærke nationale miljømærker, har valgt en differentieringsstrategi og forsøger at opretholde det nationale miljømærkets stærke position.

Svanemærket har en lignende position i de nordiske lande, og en håndhævelse af denne position kan udføres på flere måder:

${ }^{39}$ Se fx OECD databank website, http://stats.oecd.org/ 
- Først og fremmest, og som delvist nævnt ovenfor, kunne én strategi være at fokusere på sektorer og industrier med vækstpotentiale med henblik på at kunne positionere Svanemærket blandt fremtidens stærke industrier og sektorer.

- En anden mulighed er at vælge den franske strategi og mere aggressivt forsøge at adskille sig fra EU Ecolabel og fokusere på produktkategorier, i hvilke EU Ecolabel ikke er til stede.

- For det tredje kan Svanemærket differentiere sig fra EU Ecolabel ved konsekvent at sætte baren højere og indføre strengere kriterier. Blandt de fleste af de virksomheder, der var omfattet af spørgeskemaundersøgelsen eller som blev interviewet, opfattes Svanemærket allerede strengere end EU Ecolabel, og sammenligningen af kriterierne viste også, at dette i mange tilfælde gør sig gældende. En sådan strategi ville positionere Svanemærket som et "high-end" miljømærke, valgt af virksomheder, der er villige til at gøre en ekstra indsats. Dette vil naturligvis have positive miljøeffekter.

- Kommunikér fordelene ved Svanemærket klart Flere af de virksomheder, der var omfattet af spørgeskemaundersøgelsen eller som blev interviewet indikerer et $ø$ nske om en mere klar kommunikation vedr. fordelene ved Svanemærket. De ønsker at være i stand til at kommunikere til deres kunder på en kort, konkret og præcis måde, hvad fordelene ved Svanemærket er.

En sådan præcis og konkret kommunikation kan være fordelagtigt for selve Svanemærket, da det vil styrke bevidstheden om Svanemærket og dets position blandt forbrugerne og virksomhederne yderligere. Sådanne korte og præcise budskaber kunne med fordel inkluderes i kriteriedokumenterne, således at virksomhederne kan anvende disse i deres arbejde med mærket.

- Fasthold den nordiske profil Svanemærket er et stærkt brand og er kendt i alle de fem nordiske lande. Der er dog betydelige forskelle i antallet af licenshavere og varemærker på tværs af de fem lande. For at fastholde miljømærket nordiske profil, er det vigtigt, at Svanemærket har en høj prioritet i alle fem lande, og fortsætter med at udvikle og markedsføre sig som det førende miljømærke i alle de nordiske lande. 



\section{Appendix}

\begin{tabular}{|c|c|c|}
\hline & Source & Time \\
\hline The Swan Label & $\begin{array}{l}\text { http://www.nordic-ecolabel.org/criteria/ } \\
\text { product-groups/?p=3 }\end{array}$ & Beginning of January 2013 \\
\hline The EU Ecolabel & $\begin{array}{l}\text { http://ec.europa.eu/environment/ecolabel/ } \\
\text { eu-ecolabelled-products-and-services.html }\end{array}$ & Beginning of January 2013 \\
\hline Denmark & http://www.ecolabel.dk/da/virksomheder/licenser/ & $\begin{array}{l}\text { The Swan Label: } \\
\text { Beginning of January } 2013\end{array}$ \\
\hline Finland & The Swan Label: http://www.ymparistomerkki.fi/tuotteet & $\begin{array}{l}\text { The EU Ecolabel: Beginning } \\
\text { of March } 2013\end{array}$ \\
\hline Iceland & The EU Ecolabel: & Beginning of January 2013 \\
\hline Norway & $\begin{array}{l}\text { http://eu-ymparistomerkki.fi/eu-ymparistomerkki/ } \\
\text { eu-ymparistomerkin-tuotteet-ja-palvelut/tuoteryhmat/ }\end{array}$ & End of February 2013 \\
\hline Sweden & $\begin{array}{l}\text { The Swan Label http://www.ust.is/einstaklingar/ } \\
\text { umhverfismerki/svanurinn/ }\end{array}$ & End of February 2013 \\
\hline
\end{tabular}

Table 20: Sources for criteria comparison

\begin{tabular}{|c|c|c|}
\hline & The Swan Label & EU Ecolabel \\
\hline Heat pumps & $\begin{array}{l}\text { Version 2.3. } \\
14 \text { March } 2007 \text { - } 31 \text { March } 2014\end{array}$ & $\begin{array}{l}\text { Commission decision of } \\
9 \text { November 2007, 2007/742/EC }\end{array}$ \\
\hline Laundry detergents & $\begin{array}{l}\text { Version 7.3. } 15 \\
\text { December 2011- } 31 \text { December } 2015\end{array}$ & $\begin{array}{l}\text { Commission decision of } \\
28 \text { April 2011, 2011/264/EU }\end{array}$ \\
\hline Floor coverings & $\begin{array}{l}\text { Version } 5.1 \\
12 \text { Oct } 2010-31 \text { Dec } 2014\end{array}$ & $\begin{array}{l}\text { Commission decision of } \\
9 \text { July 2009, 2009/607/EC }\end{array}$ \\
\hline Tissue paper & $\begin{array}{l}\text { Version 5.0. } \\
11 \text { Oct } 2011-31 \text { Dec } 2014\end{array}$ & $\begin{array}{l}\text { Commission decision of } \\
30 \text { November } 2009 \text { 2009/967/EC }\end{array}$ \\
\hline Cleaning products & $\begin{array}{l}\text { Version } 4.6 . \\
13 \text { December } 2007 \text { - } 30 \text { June } 2014\end{array}$ & $\begin{array}{l}\text { Commission decision of } \\
26 \text { November } 2009 \text { 2010/18/EC }\end{array}$ \\
\hline Hand dishwashing detergents & $\begin{array}{l}\text { Version } 5.1 \\
21 \text { March } 2012-31 \text { March } 2016\end{array}$ & $\begin{array}{l}\text { Commission decision of } \\
9 \text { July 2009, 2009/568/EC }\end{array}$ \\
\hline Dishwaher detergents & $\begin{array}{l}\text { Version } 5.2 \\
15 \text { Dccember } 2009 \text { - } 30 \text { June } 2014\end{array}$ & $\begin{array}{l}\text { Commission decision of } \\
28 \text { June 2011, 2011/383/EU }\end{array}$ \\
\hline Copy and printing paper & $\begin{array}{l}\text { Verson } 4.0 \\
22 \text { June } 2011 \text { - } 30 \text { June } 2014\end{array}$ & $\begin{array}{l}\text { Commission decision of } \\
24 \text { June 2011, 2011/382/EU }\end{array}$ \\
\hline
\end{tabular}




\section{norden}

Nordic Council of Ministers

Ved Stranden 18

DK-1061 Copenhagen K

www.norden.org

\section{The coexistence of two Ecolabels}

This analysis looks at the synergies and positioning between the fee structures and criteria of the two ecolabels, the dissemination and success of the two labels within different product groups and the experience with co-existence between the EU Ecolabel and other national and regional ecolabels. This is done by performing interviews with representatives from the five Nordic ecolabelling secretariats and from ecolabelling secretariats in France, Germany, the Netherlands and Austria, as well as through a desk research of available material.

The analysis is conducted by DAMVAD with expert assistance from Åke Thidell, Lund University.

The project is commissioned by the Swan group under the Working Group for Sustainable Consumption and Production (HKP-gruppen) of the Nordic Council of Ministers. 